\title{
Issues and Challenges of Mangrove conservation in the Anthropocene
}

\section{Desafíos de la conservación del mangle en el Antropoceno}

\author{
Ariel E. Lugo', Ernesto Medina',2 and Kathleen McGinley'
}

1 USDA Forest Service International Institute of Tropical Forestry. Puerto Rico. alugo@fs.fed.us

\author{
2 Instituto Venezolano de Investigaciones Científicas \\ Caracas, Venezuela
}

\begin{abstract}
This essay addresses the conservation issues facing mangroves in the Anthropocene, defined as the era of human domination over the world. We review the laws, policies, international agreements, and local actions that address the conservation of mangrove forests in the Neotropics and relate them to the Anthropocene. Collaboration between governments, non-governmental organizations, and communities that depend on mangroves for their livelihood will be critical in the Anthropocene. The essay also reviews recent developments in mangrove ecology and ecophysiology that enlighten how mangroves might respond to changes in temperature and rainfall, sea level rise, and other anthropogenic and natural disturbances. Mangroves in the Anthropocene will also face changes in their species composition given the current movement of mangroves species across continental barriers as a result of human activity. These trends will lead to novel mangrove forests and in some cases expand the range of mangroves worldwide. The solution to mangrove persistence in the Anthropocene is not to isolate mangroves from people, but to regulate interactions between mangroves and humans through effective management. We will also have to expand the scope of the ecological analysis of mangrove ecosystems to include the social forces converging on the mangroves through an analytical approach that has been termed Social Ecology.
\end{abstract}

KEY WORDS: carbon fluxes, climate change, community participation, ecophysiology, mangrove cover and cover change, novel ecosystems, oligo and eutrophy, protected areas, salinity stress.

\section{RESUMEN}

Este ensayo aborda los problemas de conservación que enfrentan los manglares en el Antropoceno, definido como la época de la dominación humana sobre el mundo. En él repasamos las leyes, políticas, acuerdos internacionales y las acciones locales que se ocupan de la conservación de los bosques de mangle en el Neotrópico y se relacionan con el Antropoceno. La colaboración entre gobiernos, organizaciones no gubernamentales y las comunidades que dependen de los manglares para su sustento será decisiva en el Antropoceno. El ensayo también incluye comentarios sobre los avances recientes en ecología de manglares y en ecofisiología que explican cómo los manglares podrían responder a los cambios de temperatura y precipitación, el aumento del nivel del mar y otras perturbaciones naturales y antropogénicas. Los manglares en el Antropoceno también enfrentarán a cambios en su composición de especies, dado el actual movimiento de especies de manglares a través de barreras continentales como resultado de la actividad humana. Estas tendencias conducirán a nuevas formaciones de manglares y en algunos casos ampliarán la presencia de los manglares en todo el mundo. La solución a la persistencia de manglares en el Antropoceno es no aislar a los manglares de la gente, sino regular las interacciones entre los manglares y los seres humanos a través de una gestión eficaz. También tendremos que ampliar el alcance del análisis ecológico de los ecosistemas de manglar para incluir las fuerzas sociales convergentes en los manglares a través de un enfoque analítico que se ha denominado Ecología Social.

PALABRAS CLAVE: flujos de carbono, cambio climático, participación de la comunidad, Ecofisiología, cubierta de manglares y cambio de cubierta, nuevos ecosistemas, oligo y eutrofía, áreas protegidas, estrés de salinidad. 


\section{INTRODUCTION}

Fifty years have passed since Golley et al. (1962) published the results of a pioneer study on mangrove functioning. Other similar studies, coupled to an older and larger literature (reviewed in Lugo and Snedaker, 1974) on mangrove zonation, mangrove habitat geomorphology and ecohydrology, and mangrove ecophysiology have led to a holistic ecosystem approach to mangrove conservation. This approach is based on ecosystem-level understanding of mangroves and results in large-scale mangrove conservation schemes that consider the mangrove forest within the context of upland and marine ecosystems. These large-scale configurations of tropical mangrove landscapes approach mangrove conservation hierarchically from the regional context, to individual mangrove zones, mangrove stands within zones, and finally mangrove individuals (Twilley and Rivera Monroy, 2009).

Eleven years ago, the summary by Lugo (2002) examined the issues and challenges of mangrove conservation in Latin America. That essay highlighted the emerging consensus of the various ecological scales at which mangrove conservation must focus on, as well as the mangrove paradoxes that required scientific attention. The generalizations in that review remain relevant today and need not be reviewed again. However, a major development in the scientific field merits our attention today as we consider the challenges of mangrove conservation in this 21st century. Paul Crutzen, a Nobel Prize-winning atmospheric chemist suggested that the Anthropocene, or the era of human domination over the world, be officially designated as a geologic era that followed the Holocene (Crutzen, 2002). This proposal recognizes that human activities are so prevalent over our planet that they are changing the conditions that influence the functioning of the biota. For mangroves this means coping with a different atmospheric gas composition, sea level rise, atmospheric warming, changes in the frequency and intensity of atmospheric events, changes in hydrological conditions including levels and quality of runoff, and loss of cover as a result of urbanization, agriculture, and other land cover changes (Gilman et al., 2008; Alongi, 2008). Moreover, the biogeography of the biota of the world is also changing as a result of increased levels of commercial activities involving the movement of organisms across the globe. This global movement of the biota also affects mangroves.

Understanding and then anticipating, and where appropriate, manipulating how mangroves will respond to the environment of the Anthropocene is a scientific challenge because most of our attention to mangroves has concentrated on the conditions of the Holocene. While much of our Holocene-based knowledge will be useful and necessary to understanding mangroves in the Anthropocene, it is also true that many of the anticipated novel conditions of the Anthropocene that affect mangroves have not been studied and are thus poorly understood. A dramatic example resulted from the effects of tsunamis on the coasts of Asia. Mangrove-lined coastlines were more effective in absorbing the energy of waves than coastlines where mangroves had been removed (Danielsen et al., 2005). Many began proposing the planting of mangroves in anticipation of future tsunami events, but such activities could be ineffective, and in fact, wasteful if the mangroves are planted outside their range of tolerance to wave action. We know that mangroves grow best under low wave energy conditions, but we don't have empirical information of mangrove growth in relation to known energy levels of wave regimes. The wave energy level thresholds of mangroves have not been addressed in the mangrove literature.

In the celebration of this Journal's twenthieth anniversary, we focus our essay on the effects of the Anthropocene on mangroves based on recent estimates of mangrove cover, mangrove responses to global change, advances in the ecophysiological understanding of mangrove tree functioning, and insights into policies and institutions that affect mangroves at local to global scales. We focus on the mangroves of Latin America but also use literature from other parts of the world. Mangrove research in Latin America has increased significantly as demonstrated by the quantity and quality of presentations at the recent First Mexican Congress on Mangrove Ecosystems held at Mérida, Yucatán on October 25-29, 
2010 (http://investigacion.izt.uam.mx/ocl/Manglares2010.pdf).

Our review represents a first step for leading mangrove research towards a full understanding of their response to the Anthropocene.

\section{Mangrove Cover AND CONSERVATION POLICIES}

Mangroves are found in over 120 countries and cover more than 15 million ha worldwide (Spalding et al., 2010). Neotropical mangroves extend over 4,5 million ha, representing about 30 percent of the total global area (Spalding et al., 2010). This relative value is slightly higher than the 28 percent reported in FAO (2007), but within the range reported in Lugo (2002) based on Lacerda et al. (1993) and FAO (1994) (Fig. 1). The mangroves of Brazil extend nearly 1,3 million ha (Fig. 2) and represent 8,5 percent of the global total area (Spalding et al., 2010), second only to Indonesia (20,9 percent). Mexico and Cuba also are among the ten countries with the greatest mangrove acreage in the world (4th [5,0 percent of global total area] and 10th [3,2 percent of global total area], respectively) (Spalding et al., 2010; Giri et al., 2011).

Maps of mangroves, area estimates, and changes in their land cover over time are difficult to produce at local (Martinuzzi et al., 2009) to global scales (FAO 2007; Spalding et al., 2010). Yet, after nearly a decade of work, Spalding et al. (2010) produced a comprehensive digital world map of mangrove forests, based on relatively "good resolution data for almost all of the world's mangrove areas", enabling increasingly accurate calculations and comparisons of mangrove areas across the globe. Determining changes in mangrove cover from historical or original areas continues to be complicated due to discrepancies with data availability and measurement methods (Giri et al., 2011). For example, global mangrove area estimates in figure 1 are so variable that it is difficult to settle on a particular global area cover, although most estimates oscillate around 15 million ha. Despite ongoing challenges in mangrove measurements, it is widely agreed that the current area of mangroves is less than the original cover, but also that the rate of decline in the extent of

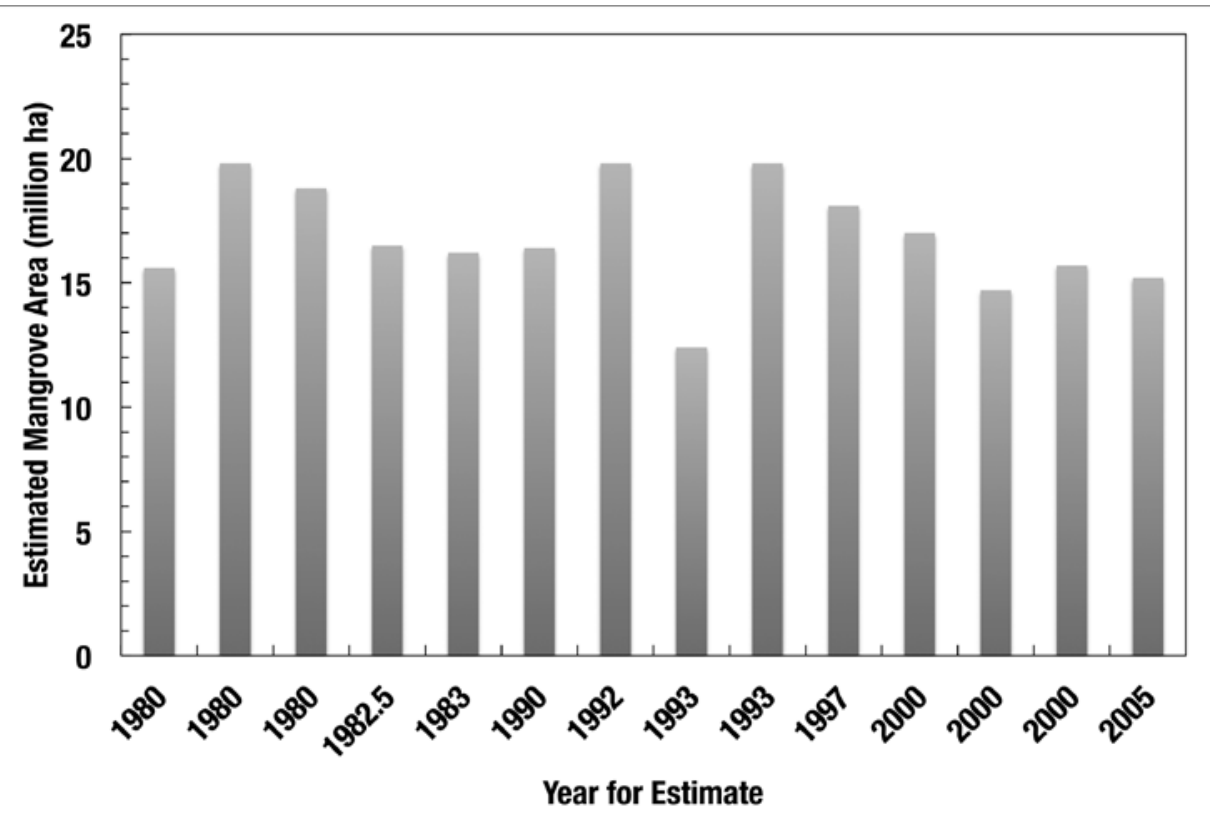

FIGURE 1. Global mangrove area at different times. Each bar represents independent estimates reported in Løyche Wilkie and Fortuna (2003) and FAO (2007). For some years, more than one independent estimate is reported. 


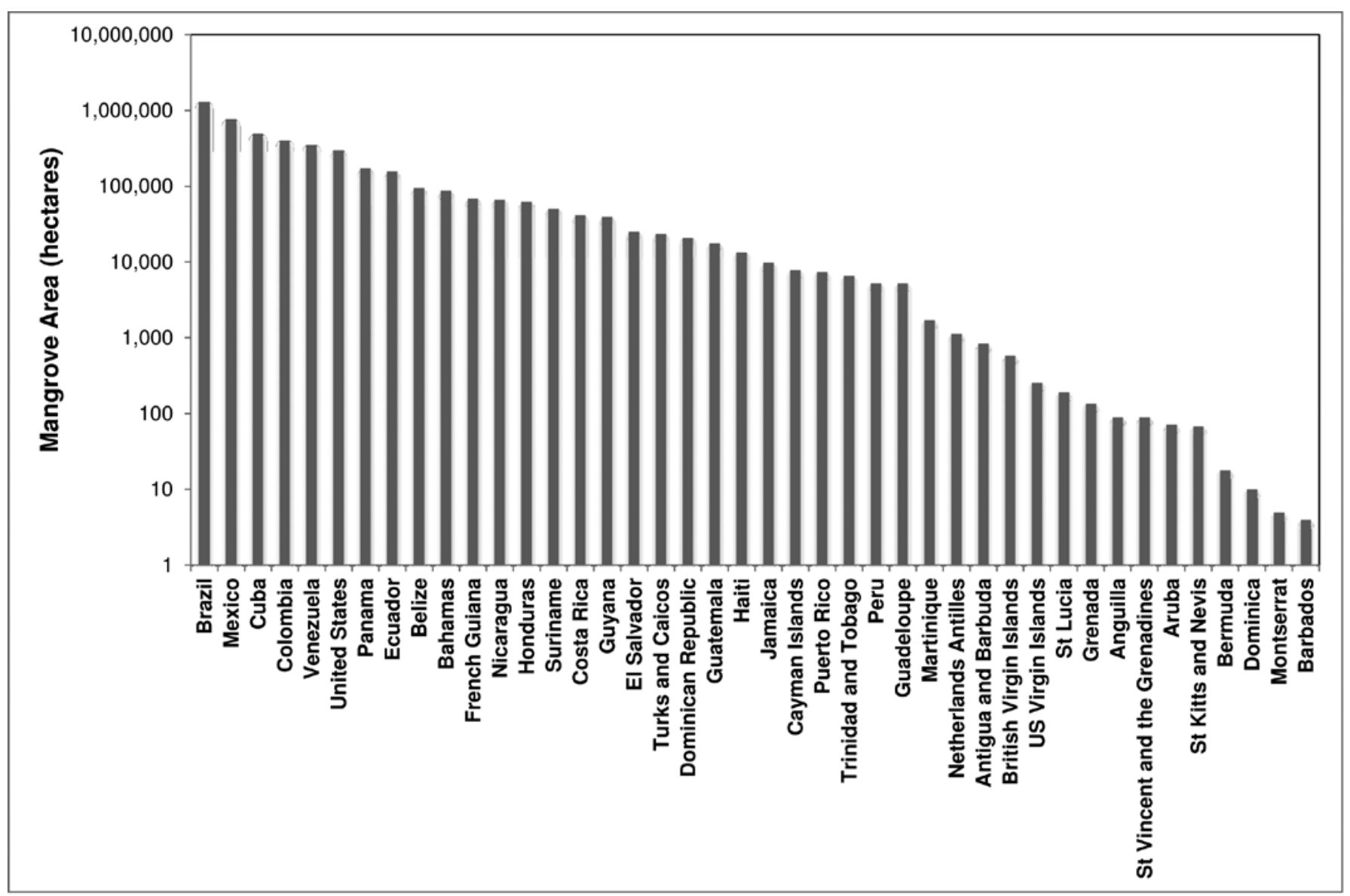

FIGURE 2. The area of mangrove forests in Neotropical countries. Countries are arranged in descending order of mangrove cover as reported by FAO (2007).

mangroves worldwide has been decreasing since about 1980 (see for example Valiela et al., 2001; FAO, 2007, Spalding et al., 2010) (Fig. 3). Nevertheless, the global loss of mangroves continues at a faster pace than the global rate of deforestation (mangrove forests: 0,66 percent per year 2000-2005; all forests: 0,18 percent per year 20002005) (FAO, 2007).

In the Neotropics, the rate of change in mangrove area varies significantly among the countries where they naturally occur. For example, between 2000 and 2005, Mexico lost the largest area of mangroves (-13 $000 \mathrm{ha} / \mathrm{yr}$ or $-1,5$ percent) followed by Honduras ( $2300 \mathrm{ha} / \mathrm{yr}$ or $-3,1$ percent), while Barbados and the US Virgin Islands had the highest annual rates of mangrove loss from 2000 to $2005(-10,6$ percent or -1 ha/yr and $-5,6$ percent or -10 ha/yr, respectively). Overall, South American mangrove areas are estimated to be declining at a slower rate than the global average and slower than the loss of mangroves in North and Central America, where "serious losses and degradation of mangroves" persist (Annual Rate of Change of Mangroves 2000-2005: Global: -0,66 percent, South America: -0,18 percent, North and Central America: $-0,77$ percent) (FAO, 2007).

As an example in contrasts, FAO data suggest that between 1980 and 2005, Colombia lost 20 percent of its mangroves, while Cuba recuperated mangrove area with an overall increase of nearly 2 percent. Although Colombia has established laws to regulate mangrove uses and some protected areas in mangrove ecosystems, poor enforcement and increasing pressure for conversion to 


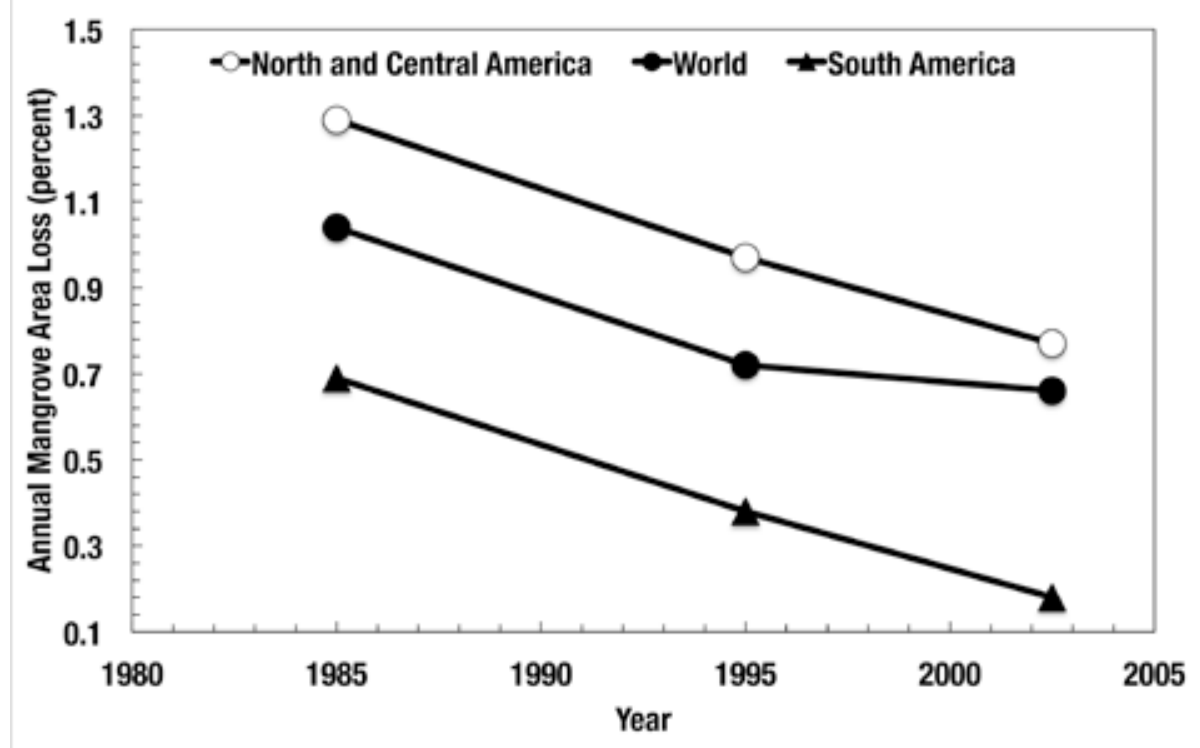

FIGURE 3. Rates of mangrove area loss based on consistent estimates by FAO (2007).

aquaculture, agriculture, and urban development have resulted in significant losses of mangrove forests. Alternatively, Cuba has invested significantly in a comprehensive mangrove conservation strategy that includes an actively managed reserve system, regulations and their enforcement, community involvement, and restoration and rehabilitation campaigns (FAO, 2007; Spalding et al., 2010).

Overall, slowing rates of mangrove loss are increasingly evident in the Neotropics and around the world. These abatements can be tied in large part to new or improved legislation, enhanced protection and conservation, expanding restoration and rehabilitation, and increasing participation of local communities and other key stakeholders in policy-making, protection, management, and monitoring (Van Lavieren et al., 2012; Spalding et al., 2010). Nonetheless, the continued decline in mangrove forests has significant environmental and socioeconomic implications, especially for communities that depend on mangroves for their livelihoods. Moreover, pressures for conversion to other land uses and from unsustainable extractive activities likely will be exacerbated by climate change, as water levels rise and coastlines shrink (Crooks et al., 2011). As pressures on mangroves are amplified in the Anthropocene, we must identify effective policies and practices that enhance the sustainability of people-nature relations, which is the focus of the remainder of this section.

\section{Protected AREas}

The first line of defense for many mangrove systems is their designation for protection or sustainable management in formal reserve systems. Strictly protected areas (IUCN Categories I-IV) encompass approximately 14,2 percent of all mangroves worldwide (Schmitt et al., 2009). Including protected areas that permit sustainable use and harvest (IUCN Categories I-VI) increases the mangrove area under protection to nearly 21 percent, which is higher than the percent of all forests worldwide that are found within protected areas (13,5 percent) and higher than most other global forest types (e.g., tropical mangroves are ranked $5^{\text {th }}$ out of 20 global forest types in terms of IUCN I-IV and I-VI percent protection) (Schmitt et al., 2009). In Brazil, for example, more than 82 percent of the country's mangroves are located within protected areas, 77 percent of which permit the sustainable harvest of resources (Gravez et al., 2013). 
Including mangrove areas under international conventions is an additional measure that can strengthen national or subnational level protection measures. Three global agreements in particular are important to mangrove protection: the Convention on Wetlands of International Importance, also known as the Ramsar Convention, with 175 sites in the Neotropics; the UNESCO Man and the Biosphere Program with 117 Biosphere reserves in Latin America and the Caribbean; and the World Heritage Convention, with 129 sites in the region. Many of these sites encompass mangrove systems, particularly those recognized under the Ramsar Convention. In Mexico, 45 Ramsar sites cover more than 64 percent of the total mangrove area. Also, many of these sites overlap with most of the 32 federal protected areas that encompass approximately 43 percent of the total mangrove area (Spalding et al., 2010). Other international agreements that are directly relevant to the conservation of mangrove biodiversity are the Convention on Biological Diversity and the Convention on the International Trade of Endangered Species. Together, these agreements promote better protection of mangroves and other threatened ecosystems and species, increased awareness and recognition of their importance, and reinforce national-level legal frameworks and institutions.

While the number and area of mangroves in reserve systems continue to grow in Latin America and the Caribbean, many are hardly more than 'parks-on-paper' whose mangroves and associated biodiversity are vulnerable to degradation. These 'paper parks' typically result from limited capacity and resources for enforcing boundaries and related regulations and poor inter-institutional collaboration and coordination. Even when sufficiently staffed and financed, protected mangroves can come into conflict with local communities and other resource users, particularly if they are excluded from the area without compensation for lost livelihoods (see for example Mora and Sale, 2011; Gravez et al., 2013; Van Lavieren et al., 2012). Moreover, when we consider the probability for species and ecosystem shifts, both locally and globally, under the conditions of a changing climate and everincreasing human interventions, the viability of the exis- ting network of protected areas, at local to global levels, must be reexamined to find ways for increased connectivity between current conditions and potential future movements.

\section{REGULATIONS AND OTHER LEGAL PROTECTIONS}

Mangroves are also protected through regulations and other legislation. Some countries have incorporated mangrove conservation into broad-scale policy guidelines or framework legislation (e.g., Belize, Cuba), endorsing a holistic concept of mangroves as part of the larger landscape and across levels of government (Spalding et al., 2010). Many countries have established laws and regulations preventing alteration or conversion of mangroves or requiring a license for their use or harvest that must be authorized by the designated authority (e.g., Barbados, Belize, Brazil, Colombia, Costa Rica, Cuba, Ecuador, El Salvador, Guatemala, Jamaica, Mexico, Panama, Peru, Puerto Rico, Trinidad and Tobago, Us Virgin Islands, Venezuela). For instance, in Brazil, mangroves are protected under the federal Forest Law and are designated as Areas of Permanent Preservation through the Forestry Code. Total or partial removal of mangrove vegetation is prohibited without authorization from the relevant government agencies and only when deemed to be in the "public interest" (Almeida Magris and Barreto, 2010).

In Mexico, where mangroves extend more than 770000 ha (Conabio, 2009), but annual losses persist at rates greater than 1,5 percent per year, legal protections intended to safeguard mangroves were rescinded in 2004, largely due to pressure from coastal developers (FAO, 2007; Van Lavieren et al., 2012). In 2007, legislation on mangroves was restored and strengthened to provide for their absolute protection. Yet, enforcement remains a challenge, particularly because human and fiscal resources limit state agencies while tourism developers continue to push for reduced regulations (Spalding et al., 2010). Similarly, in El Salvador, due to concerns over mangrove losses, a complete ban on mangrove logging was established in 1992. However, illegal logging and other unauthorized 
uses of mangroves have continued across their range, due in large part to limited resources for law enforcement and to complex and expensive regulations that make illegality a more attractive option for most mangrove users (Gammage et al., 2002).

In Puerto Rico, mangroves demonstrate measurable resiliency despite large-scale land cover changes. Throughout the 1800s, mangroves experienced a steady decline in area that is associated with intensive agriculture, which was followed by a rapid increase in area with the abandonment of agricultural activities (Fig. 4). Urbanization also caused mangrove decline in the 1960s, but with the passage and enforcement of conservation laws and regulations, alongside increasing awareness of and public support for mangroves, mangrove area is rebounding. The trajectory of mangrove cover in Puerto Rico shows that even where there are significant losses of mangroves to deforestation and other activities, the pattern can be reversed if policies are in place and publicly supported and where the conditions that lead to mangrove regeneration continue to sustain their renewal.

\section{COMMUNITY PARTICIPATION}

Countless communities throughout the Neotropics depend on mangroves as their primary food and fuelwood source and for protection from storms and coastal erosion. Yet, traditional conservation strategies, aimed at protecting mangroves through, for example, strict protection or regulation, often result in lost revenue or adverse social effects, particularly when local communities are excluded from decision-making and/or removed from the ecosystem (Fujita et al., 2013). And, while community participation is no panacea in and of itself for environmental degradation, effective resource management and conservation increasingly depend on the inclusion and involvement of local communities in related policymaking, management and monitoring (see for example Gibson et al., 2000; Van Levieren et al., 2012).

In Ecuador, the government is experimenting with several new forms of collaborative natural resource governance, including Mangrove Ecosystem Concessions, which are 10-year contracts between the Ministry of Environment and native communities or other organized

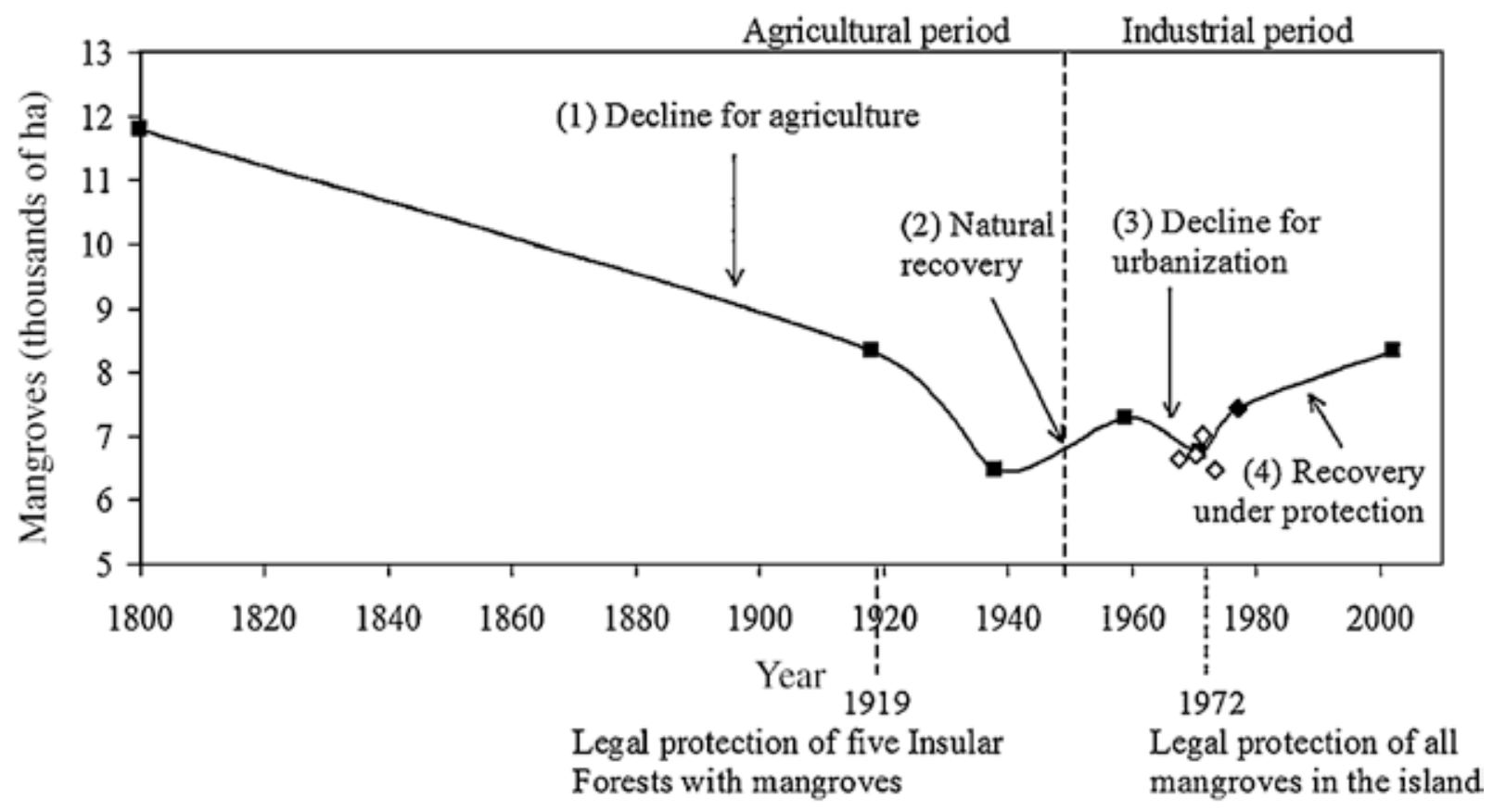

FIGURE 4. The historical decline and increase of mangrove cover in Puerto Rico as reported by Martinuzzi et al. (2009). 
groups that grant the concessionaire with the rights to harvest seafood and monitor and prevent illegal deforestation (timber harvesting is prohibited) (Gravez et al., 2013). These concessions are the only type of marine protected area in Ecuador in which local stakeholders have clear, legal title to usufruct resource rights. The majority of the more than 40 mangrove concessions covering nearly 40000 ha are proving effective in curbing deforestation, sustaining increased seafood yields, improving livelihoods, empowering concession holders, and reducing conflicts with the large-scale shrimp industry. "Increased participation has led to debate and action on long-neglected problems, with positive social and ecological results, most notably in mangrove concessions" (Gravez et al., 2013).

Similarly, in Brazil, the establishment of large extractive reserves in mangrove forests offers an alternative management approach to strict protected areas that generally exclude local inhabitants. In the extractive reserves, control and ownership of natural resources is conferred to local communities who regulate access to and harvest of timber and fishing resources. Saint Paul (2006) found that many of these extractive reserves were more effective at protecting the area and resources of mangrove and other forests than reserves managed by the Federal Government of Brazil.

\section{FINANCIAL INSTRUMENTS}

Although mangroves are increasingly incorporated into reserve systems and addressed through legal restrictions and other regulations, mangrove loss and degradation persist, due in part to their 'incomplete' valuation in the modern marketplace (Fujita et al., 2013). Financial instruments, such as payments for environmental services, conservation easements and mitigation banking, along with expanded markets that value a broader suite of goods and services could greatly enhance the conservation of mangroves, though successful examples of such programs are scarce. Challenges for creating these new markets and incentives include unclear property and tenure rights, overlapping jurisdictions and responsibilities, and weak institutional frameworks (Fujita et al. 2013).
An emerging economic strategy for mangrove conservation is their inclusion in carbon balance sheets that are being developed as part of international negotiations to address global climate change. Mangroves are important carbon sinks (discussed below) and play a significant role in climate change adaptation and disaster risk mitigation. Under the right conditions (e.g., clear tenure and usufruct rights, international support), the inclusion of mangroves in carbon accounting would permit the establishment of mechanisms for payments through carbon markets, such as those expected to develop through the Reduced Emissions from Deforestation and Forest Degradation (REDD+) scheme under the UN Framework Convention on Climate Change and its Kyoto Protocol (Van Lavieren et al., 2012). These payments could offset persisting market failures and boost mangrove conservation, especially in developing countries, which hope to benefit from carbon markets developed under REDD+.

In sum, there are many policy approaches in place to conserve mangrove forests throughout the Neotropics. Mangroves are well represented in protected area systems and are further protected through governmental regulations and other policy directives related to their use. However, even where protected areas and conservation policies exist, effective implementation and enforcement remain a challenge, particularly in places with limited resources and capacity and where there are pressures for conversion and from other intensive land uses (FAO, 2007). Moreover, unclear property rights or overlapping authority for mangrove systems by multiple agencies, communities, or individuals can lead to conflicts and exacerbate mangrove degradation and conversion (Van Lavieren et al., 2012; Ostrom, 2000; Gibson et al., 2000). Some of the challenges in governing mangrove ecosystems are associated with market failures that may be corrected in part through the development of financial incentives and eco-markets that cover a broader array of mangrove goods and services. Ultimately, effectively governing human interactions with mangrove environments, particularly in the context of the Anthropocene, will require more meaningful and explicit stakeholder participation, as well 
as increasing adaptiveness in decision-making, management, and monitoring.

\section{MANGROVE ECOPHYSIOLOGY}

Mangrove ecosystems are characterized by their occurrence along environmental gradients at local and global scales. For example, mangroves respond globally to latitudinal temperature gradients, while locally, gradients of soil salinity are common. Therefore, understanding the ecophysiological responses of mangrove trees to environmental gradients is essential considering the limited number of mangrove species that occur along these gradients. This knowledge is of critical importance to conservation in the Anthropocene because monospecific mangrove zones usually reflect species responses to prevailing conditions along complex environmental gradients (Lugo, 1980). As these gradients change, it will be possible to infer their effects through the understanding of mangrove species ecophysiology. The success and cost-effectiveness of reforestation, restoration, and even species eradication efforts will benefit from the understanding of ecophysiological responses of mangroves to prevailing and anticipated environmental conditions.

The literature on mangrove ecosystems has rapidly increased during the last 15 years, since the publication of the now classic book The Botany of Mangroves (Tomlinson, 1986), and a number of relevant reviews have been written on the ecology and physiology of mangrove ecosystems components (Ball, 1988; Medina, 1999; Kathiresan and Bingham, 2001; Lüttge, 2002, Komiyama et al., 2008; Gilman et al., 2008; Liang et al., 2008; Parida and Jha, 2010; Reef et al., 2010; Feller et al., 2010; Wang et al., 2011). Here we will emphasize some aspects that appear to us particularly relevant for understanding the physiological ecology of mangroves in the Anthropocene.

\section{The EnVironmental Problems Facing MANGROVES}

Mangroves are intertidal plant communities occurring along the low energy shores of tropical, subtropical, and warm temperate regions. They thrive under a multi-stress environment characterized by variable salinity, determined essentially by $\mathrm{NaCl}$ of marine origin, oscillating low oxygen stress determined by flooding of variable duration and depth, and particularly in the tropics, conditions of year round high radiation stress. Toward warm temperate areas, the reduction in air temperature, and occasional occurrence of frosts, constitutes a further stress factor determining the latitudinal limits of mangrove species distribution. On top of this set of environmental stresses, nutrient availability is frequently limited in some mangroves reducing their productive and competitive capacity. Finally, seawater, to which mangroves are adapted to, is a highly unfavorable nutrient solution, toxic to most angiosperm plants due to the high concentration of chloride and sulfate, and non-physiological $\mathrm{K} / \mathrm{Na}$ and $\mathrm{Ca} / \mathrm{Mg}$ ratios.

The environmental "problems" facing mangroves may be depicted as follows: propagules establish in moist or wet sediments, with variable salt concentration in the interstitial water, in open or partially shaded areas covered by adult mangrove trees. The embryos are rich in energy supplies derived from the mother plant, and the emerging rootlets face an aqueous environment of low water potential due to the presence of abundant marine salts (mainly chlorides and sulfates of $\mathrm{Na}, \mathrm{Mg}$, and $\mathrm{Ca}$ ). Expansion of photosynthetic surface depends on the flow of water from the soil through the xylem to the canopy. For this process to take place, a positive differential of water potential has to be established between the soils and the plant. The energy for this derives from the evaporative potential of the atmosphere expressed as leaf-air vapor pressure deficits amounting to several tens of $\mathrm{MPa}$. Water uptake under those conditions is necessarily associated with uptake of ions. Many mangrove species severely restrict excess uptake of $\mathrm{Na}^{+}$ions by the roots, but not so much of $\mathrm{K}^{+}$, so that the solution flowing through the xylem to the leaves has lower concentrations of the former compared to the interstitial water (Scholander et al., 1962). Other species are less restrictive, allowing transportation of substantial amounts of $\mathrm{Na}$ to the leaves. In both cases salt transported in the transpiration stream accumulates sooner or later in both root and leaf tissues, reaching toxic 
concentrations. For this reason, transpiration is low in mangroves compared to trees from humid, non-saline environments. In addition, resistance to sap flow in xylem vessels is affected by its salt concentration in a little understood process (Sobrado, 2000). Reduction in transpiration diminishes the capacity of leaf cooling through loss of latent heat. Thus, in mangroves, water and salt budgets interact in the regulation of leaf conductance and temperature.

\section{AdAPTATIONS TO MULTI-STRESS ENVIRONMENTS}

Responses to this multi-stress environment are diverse and include mechanisms of evasion, structural development, biochemical regulation, and physiological interactions that account for the successful establishment, growth, and reproduction of the small group of true mangrove trees. Although mangroves are often treated as a homogeneous group they are constituted by a small set of species differing widely in genetic origin and their physiological properties regarding salinity tolerance, growth habit, and dispersal capability (Tomlinson, 1986; Saenger, 2002). In the case of mangrove species native to the American continent, there are seven truly halophytic species and several species differing in salt tolerance found associated to mangrove systems in humid areas (Table 1), whose physiological properties are little known (Duke et al., 1998; Medina, 2000; Mehlig et al., 2010).

Propagule Dispersion and Resprouting Ability. Differences in resprouting capability explain variations in regeneration dynamics after strong disturbances, such as hurricanes. In mangrove areas affected by hurricane Andrew in Florida, Rhizophora mangle regenerated primarily via growth of seedlings present at the time of the hurricane, but trees of Avicennia germinans and Laguncularia racemosa resprouted abundantly from dormant epicormic buds (Baldwin et al., 2001). Amount and size of propagules also influence dynamics of establishment. In the Atlantic coast mangroves of Venezuela, L. racemosa behaves as a pioneer species occupying rapidly open sediments, followed by A. germinans and later by the slower growing $R$. mangle, with heavier propagules (Rivera Monroy et al., 2004).

Flood Tolerance. Tolerance to flooding and hypoxic substrates results from processes similar to those observed in fresh water swamp trees, and all are related to anatomical features facilitating oxygen transport to roots, i.e., pneumatophores and aerenchyma development in roots and stem bases. Mangrove trees effectively oxygenate their substrate, a process that is evidenced by the precipitation of iron oxide surrounding roots within the hypoxic substrate. This process is also responsible for the oxidation of highly toxic hydrogen sulfide that accumulates in organic matterrich hypoxic sediments surrounding mangrove roots in their natural environment. Substrate oxygenation is brought about by tidal energy facilitating expulsion of respiratory $\mathrm{CO}_{2}$ accumulated within intercellular space in the root aerenchyma during high tides, and inflow of $\mathrm{O}_{2}$-rich air during low tides (Scholander et al., 1955).

Heat Stress and Photoinhibition. High radiation may lead to overheating of photosynthetic surfaces, particularly in environments where water uptake is hindered by high salinity in the interstitial water surrounding roots. Most true mangroves are characterized by a pronounced degree of leaf inclination, a sort of avoidance mechanism reducing the amount of visible and infrared radiation absorbed by leaves. In addition, variations in leaf area and succulence contribute to maintain leaf temperatures near air temperatures with minimal evaporative cooling (Ball et al., 1988). Similar avoidance responses are observed in vegetation from dry areas (Gates et al., 1968) and even in humid areas in soils with low water retention capacity (Medina et al., 1978). Tolerance to extreme temperatures is one of the least known properties of mangrove leaves. The few data available indicate that the temperature tolerance ranges from $1{ }^{\circ} \mathrm{C}$ to $50{ }^{\circ} \mathrm{C}$ in $R$. mangle, A. germinans and L. racemosa (Biebl, 1965). Usually, optimum temperature for photosynthesis in several mangroves species is below $35^{\circ} \mathrm{C}$ (Ball, 1988). But in a Rhizophora spp., photosynthetic rate decreases linearly at temperatures above $30^{\circ} \mathrm{C}$ reaching negative values at $45^{\circ} \mathrm{C}$ (Cheeseman et al., 1997). This subject requires experimental analysis 
TABle 1. American mangroves and mangrove-associated species. Tree (T), shrub (S), and vine (V). Asterisks in the salinity tolerance column indicate: *** halophytes; $* *$ on sediments flooded by seawater; * on sediments flooded with brackish water. By * and ** no salinity tolerance study is known to us. Empty cells mean no information available (Popp et al., 1985, 1993; Popp and Polania, 1989; Medina, 2000; Medina et al., 1990).

\begin{tabular}{|c|c|c|c|c|}
\hline Family and Species & Habit & Salinity Tolerance & Salt Balance & $\begin{array}{c}\text { Compatible Solutes in } \\
\text { the Genus }\end{array}$ \\
\hline \multicolumn{5}{|l|}{ True Mangroves sensu Tomlinson (1986) } \\
\hline \multicolumn{5}{|l|}{ Avicenniaceae } \\
\hline Avicennia germinans (L.) L. & T-S & $* * *$ & Excretion & $\begin{array}{l}\text { Quaternary ammonium } \\
\text { compounds }\end{array}$ \\
\hline Avicennia bicolor Standl. & T-S & $* * *$ & Excretion & \\
\hline $\begin{array}{l}\text { Avicennia schaueriana St. \& Lec. Ex Mold. } \\
\text { Combretaceae }\end{array}$ & T-S & *** & Excretion & \\
\hline Laguncularia racemosa (L.) C.F. Gaertn. & T-S & $* * *$ & $\begin{array}{l}\text { Excretion-succu- } \\
\text { lence }\end{array}$ & mannitol \\
\hline \multicolumn{5}{|l|}{ Tetrameristaceae } \\
\hline Pelliciera rhizophorae Planch. et Triana & $\mathrm{T}$ & *** & Exclusion & \\
\hline \multicolumn{5}{|l|}{ Rhizophoraceae } \\
\hline Rhizophora mangle L. & T-S & *** & Exclusion & $\begin{array}{l}\text { Ortho-methyl-muco- } \\
\text { inositol }\end{array}$ \\
\hline Rhizophora racemosa C. Mey & $\mathrm{T}$ & *** & Exclusion & \\
\hline \multicolumn{5}{|l|}{ Species Associated With Mangroves } \\
\hline \multicolumn{5}{|l|}{ Annonaceae } \\
\hline Annona glabra & T-S & * & & \\
\hline \multicolumn{5}{|l|}{ Apocynaceae } \\
\hline Rhabdadenia biflora & V & $* *$ & & \\
\hline \multicolumn{5}{|l|}{ Arecaceae } \\
\hline Bactris major & $\mathrm{T}$ & * & & \\
\hline \multicolumn{5}{|l|}{ Bignoniaceae } \\
\hline Tabebuia palustris Hemsl. & T-S & & & \\
\hline \multicolumn{5}{|l|}{ Combretaceae } \\
\hline Conocarpus erectus L. & T-S & *** & Exclusion & mannitol \\
\hline \multicolumn{5}{|l|}{ Fabaceae } \\
\hline Dalbergia ecastaphyllum (L.) Taub. & S & * & & \\
\hline Machaerium lunatum (L.) Ducke & T-S & ** & & \\
\hline Muellera frutescens & S & * & & \\
\hline \multicolumn{5}{|l|}{ Lytraceae } \\
\hline Crenea maritima Aubl. & S & ** & & \\
\hline \multicolumn{5}{|l|}{ Malvaceae } \\
\hline Hibiscus pernambucensis Arruda & T-S & * & & $\begin{array}{l}\text { Quaternary ammonium } \\
\text { compounds }\end{array}$ \\
\hline Pavonia spicata Cav. & S & * & & \\
\hline Thespesia populnea (L.) Sol ex Corrêa & T-S & ** & & \\
\hline \multicolumn{5}{|l|}{ Moraceae } \\
\hline Mora oleifera (Triana ex Helms) Ducke & $\mathrm{T}$ & * & & \\
\hline \multicolumn{5}{|l|}{ Pteridaceae } \\
\hline Acrostichum aureum L. & S & ** & & $\begin{array}{c}\text { Ortho-methyl-muco } \\
\text { inositol }\end{array}$ \\
\hline
\end{tabular}


because temperature acclimation may induce variation in optimal temperatures of several degrees (Iba, 2002). However, temperatures above $40{ }^{\circ} \mathrm{C}$ approach the absolute limits of growth in higher plants (Berry and Björkman, 1980). The high levels of solar radiation with restriction in water supply due to salinity, might lead to disruption of the photochemical machinery in the chloroplasts in a process known as photoinhibition (Demmig et al., 1987). However, measurements under natural conditions do not reveal occurrence of chronic photoinhibition in several mangrove species (Cheeseman et al., 1997; Naidoo et al., 2002).

Interstitial water osmolality and cellular salt compartmentalization. The environmental stress selecting for a specialized physiology and biochemistry is the elevated ion concentration characteristics of marine coasts where mangrove vegetation establishes and reproduces. This stress is not avoidable under natural conditions because water available for uptake is always saline. A certain degree of avoidance may be represented by the filtration of salt during water uptake at the root level, but this process does not prevent salt accumulation in the mangrove photosynthetic tissues on the long-term. Salt concentration in the mangrove xylem sap may be low but the continuous demand for water leads to unavoidable salt accumulation at the photosynthetic surfaces.

The main effort in the study of ecophysiology of mangroves has been on their tolerance to salinity, and how it affects growth and photosynthesis (Clough, 1984; Tomlinson, 1986; Ball, 1988; Medina, 1999). Mangroves are considered true halophytes, indicating that they can complete their biological cycle, from establishment to reproduction, under salinity conditions ranging from nearly fresh water to up to three times the concentration of standard seawater $(\approx 35 \%$ \%). Recently the question on whether mangroves are "obligate or facultative halophytes" has been brought up in the literature (Wang et al., 2011; Krauss and Ball, 2013). Analysis of mangrove tissues growing under natural conditions are well known for the predominance of $\mathrm{Na}$ and $\mathrm{Cl}$ ions, and in some cases $\mathrm{SO}_{4}$ ions (Walter and Steiner, 1936; Popp, 1984; Smith et al., 1989). Besides, in nearly freshwater wetlands mangrove species such as $R$. mangle accumulate $\mathrm{Na}^{+}$ions to concentrations approaching that of standard seawater (Table 2; Medina et al. 1995, 2005, 2008). Mangroves cultivated in nutrient solutions without added $\mathrm{NaCl}$ and with increasing concentrations of this salt show frequently an optimum response at salinity levels around 10 to 25 percent of standard sea water (Pannier, 1959; Downton, 1982; Naidoo and von Willert, 1999; Suárez and Medina, 2006).

Accumulation of salts in leaf tissues is toxic, and leads to impairment of leaf functions. The salty solution transported in the xylem lifted by the root-leaf water potential gradient fills up the intercellular spaces of the leaves. This elicits responses induced by the osmotic potential of the intercellular solution, initially causing shrinking of the leaf tissues, and also activating $\mathrm{Na}$ transporters that either prevent $\mathrm{Na}$ intake into the cytosol or promote its transport to the vacuole (Liang et al., 2008).

Mangrove species have developed a variety of biochemical mechanisms leading to increases in protoplasmic tolerance to salt. Accumulation of ions within the vacuole creates an osmotic imbalance within the cell that leads to cytosol dehydration. This imbalance is counteracted by the accumulation in the cytosol of the so called "compatible solutes", compounds that can be accumulated in concentrations large enough to balance the osmotic potential of the vacuolar sap, but that do not impair enzymatic function in the cytosol (Wyn Jones and Gorham, 2002). The best known of those compounds is the iminoacid proline. This compound accumulates in many angiosperms, in response to drought stress. In halophytic plants it has been shown that the increases in external salt concentration induces accumulation of proline, in a process that may be related to drought stress (concentration effect of the external solution). Other compounds common in mangroves are betaines, specially glycinbetaine in the black mangrove A. germinans, and polyoles such as D-mannitol in L. racemosa and Aegiceras corniculatum, pinitol in Aegialitis annulata and D-1-Omethyl mucoinositol in species of Rhizophora and in the sporophyte of the mangrove fern, Acrostichum aureum 
TABLE 2. Average osmolality and ionic composition of leaf sap from wetland trees in non-saline coastal wetlands in the Maracaibo basin. The cation ratio was averaged for all samples, not from average concentrations. For the leaf samples number in columns followed by the same letter are not statistically different ( $\mathrm{p}>0,05)$ (Medina et al., 2005).

\begin{tabular}{|c|c|c|c|c|c|}
\hline Sample & $n$ & Osmolality & $\mathrm{Na}$ & $K$ & $\mathrm{Na} / \mathrm{K}$ \\
\hline & & (mmol/kg) & \multicolumn{2}{|c|}{$\left(\mathrm{mol} / \mathrm{m}^{3}\right)$} & \\
\hline Standard Sea Water & & 1000 & 459 & 9,7 & 47,4 \\
\hline Wetland Water & $42-46$ & 31 & 13 & 0,5 & 17,6 \\
\hline \multicolumn{6}{|l|}{ Rhizophora mangle } \\
\hline Adult leaves & 24 & $1036 a$ & $165 a$ & $119 a$ & 1,5 \\
\hline Senescent leaves & 21 & $944 a$ & $179 a$ & $102 a$ & 2,0 \\
\hline \multicolumn{6}{|c|}{ Hibiscus pernambucensis } \\
\hline Adult leaves & 10 & $602 b$ & $146 a$ & $72 a b$ & 4,0 \\
\hline Senescent leaves & 7 & $543 b c$ & $154 a$ & $44 b$ & 6,2 \\
\hline \multicolumn{6}{|l|}{ Pterocarpus officinalis } \\
\hline Adult leaves & 8 & $442 c$ & $27 b$ & $88 a b$ & 0,5 \\
\hline
\end{tabular}

(Table 1). Accumulation of these compounds has associated metabolic costs. In the case of polyols, the cost is comparatively small in terms of carbon. In the case of glycinbetaines and other quaternary ammonium compounds, however, the demand for additional $\mathrm{N}$ beyond the amount required for photosynthetic enzymes increases the concentration of $\mathrm{N}$ of mangroves species accumulating this type of compound. This probably explains why Avicennia species have consistently higher concentrations of $\mathrm{N}$ in their leaves compared to other mangroves (Medina and Francisco, 1997; Lovelock and Feller, 2003; Lugo et al., 2007).

\section{Structural DEVELOPMENT, SALINITY, AND NUTRIENTS.}

One of the most impressive features of mangrove communities is their range of structural development, described as structural plasticity. Tall communities of R. racemosa, R. mangle and A. germinans are found along the humid Atlantic coasts of northern South America containing trees surpassing $30 \mathrm{~m}$ height (Bacon, 1990; SchaefferNovelli et al., 1990; Twilley and Medina, 1996; Medina and Francisco, 1997; Rivera Monroy et al., 2004; Mehlig et al., 2010). The opposite extremes are found in the Caribbean where dwarf $R$. mangle and A. germinans mangroves have been studied in Florida, Puerto Rico, Belize, and Panama (Pool et al., 1977; Lin and Sternberg, 1992a, b; Feller, 1995; Medina et al., 2010).

Dwarf mangroves should not be confused with stunted mangroves of similar height. A stunted mangrove has reduced height because of environmental stresses such as high salinity or wind (Cintrón et al., 1978; Naidoo, 2006). Leaf size in stunted mangroves is also reduced by the environmental stress. However, a dwarf mangrove maintains normal leaf size but its height is reduced. In the Caribbean, dwarf Rhizophora communities are common on flooded peat substrates overlying carbonate layers. The peat originates mostly from the accumulation of their own debris, mainly recalcitrant roots that do not decompose in the hypoxic substrate. In a groundbreaking study, Feller (1995) showed in Rhizophora communities in Belize that dwarfing was caused by P deficiency, and it can be at least partially overcome by fertilization. Several studies confirmed this finding and described the complex N-P relationships in these communities (Feller et al., 1999; McKee et al., 2002; Feller et al., 2002; Lovelock et al., 2006c). 
These findings are also relevant to predicting the effect of coastal eutrophication on mangroves. Lovelock et al. (2009) compared several research sites around the world and concluded that increase in nutrient availability can increase mangrove mortality particularly in semiarid coasts. The fertilization effect was detected only on $\mathrm{N}$-fertilized scrub mangroves stressed by hypersaline conditions. Authors argued that increased fertilization is bound to increase shoot/root ratios, and thus render the plants more vulnerable to salt and drought. However, as this effect was not observed on fringe mangroves, and P fertilization treatment did not influence mortality rates, the results do not support the generalization of the initial statement.

Differences in Photosynthesis and Water Use-Efficiency. Lin and Sternberg (1992a, b) conducted a series of comparative studies between fringe and scrub mangroves in Florida. The study showed higher water use-efficiency, both short- and long-term, in scrub mangroves species (R. mangle, L. racemosa and A. germinans), and the differences were attributed more to leaf conductance than to absolute rates of photosynthesis. The study suggested that the differences in structural development were due to higher salinity and poorer aerations conditions in the scrub mangrove communities. Higher water use-efficiency in scrub mangroves is a result of stomatal limitation on photosynthesis, which may entail considerable carbon cost to the plants.

Cheeseman and Lovelock (2004) compared fringe and dwarf Rhizophora trees in Belize reporting that leaf photosynthetic rate is saturated at irradiation levels just above $500 \mu \mathrm{mol} \mathrm{m}^{-2} \mathrm{~s}^{-1}$ in both communities, but photosynthetic response in control and $\mathrm{P}$ or $\mathrm{N}$ fertilized plants did not show a clear pattern. Differences in gas exchange did not remain constant throughout the year, but dwarf mangroves had higher long-term water useefficiency as indicated by $\delta^{13} \mathrm{C}$ values. McKee et al. (2002) observed in dwarf P-limited Rhizophora stands in Belize that higher $\delta^{13} \mathrm{C}$ values indicating higher longterm water use-efficiency were reduced when fertilized with $\mathrm{P}$ but not with $\mathrm{N}$. These results are related to changes in hydraulic conductivity discussed further below.

Hydraulic Structure and Conservative Water Use. One aspect relatively neglected in the study of mangrove physiological ecology is the relationship between resistance to water transport from roots to leaves in trees growing on saline soils. Mangroves in general develop large water deficits, expressed as water potentials as low as those typical for plant from dry areas growing under chronic water deficiency. Restrictions in water availability under conditions of high atmospheric evaporative demand, increases the probability of xylem cavitation, the breaking of liquid columns in xylem vessels, leading to embolism, and reduction of water flow to the leaves (Ewers et al., 2004; López-Portillo et al., 2005; Robert et al., 2009). Hydraulic properties of roots, stems, and leaves have to be coupled to regulate water losses at the leaf levels, i.e., stomatal regulation of transpiration. In fact, hydraulic conductance and stomatal regulation appear to be coupled together and thus prevent xylem embolism. When evaporative demand is high and transpiration stream cannot cover water loss, stomata close, thus preventing embolism (Franks and Brodribb, 2005).

In seasonally humid tropical climates in the American continent a distinct pattern in the distribution of mangrove species occurs. Rhizophora spp. dominates the coastline in contact with sea, estuarine, or fresh water (fringe), whereas Avicennia spp. tends to dominate in the back of the mangrove community towards the interior (basin), away from the fringe. Laguncularia racemosa occupies intermediate zones or is found scattered within fringe and basin depending on the incidence of direct rainfall or superficial run-off. A variety of explanations have been put forward to explain this differentiation in terms to tolerance to flooding and/or salinity. Avicennia spp. in general is considered to be more salt resistant, but also to tolerate seasonally variable salinity levels, thus considered as an euryhaline species. Rhizophora spp. on the contrary, may be considered to be stenohaline, because in spite of their high salinity tolerance, they avoid sites with large salinity fluctuations. Consistent with the salinity environ- 
ment, Mendoza et al. (2012) found in northern Brazil a greater redox variation and higher oxidation in the root zone of Avicennia than in the Rhizophora root zone.

Sperry et al. (1988) compared the hydraulic properties of stems from two species of the Rhizophoraceae, occurring in contrasting environments, $R$. mangle by the sea, and Cassipourea elliptica from rain forest. It was shown that the hydraulic properties corresponded to the environmental demands in which each species occurred. Since then, detailed analyses of the relationships between gas exchange, anatomy of water conducting tissue, and hydraulic architecture of mangrove trees have been published by several laboratories. Sobrado (2000) set the basis for understanding the relationships between photosynthetic performance and stem hydraulic properties and the ecological implications for mangrove species under natural conditions. The study showed that the three common mangrove species in the Caribbean have hydraulic conductances at the lower end of the range reported for tropical trees. In addition, these species showed specific differences related to the environment in which they usually occur. She found that L. racemosa and A. germinans were more conservative in water use, a characteristic that may be advantageous in soils with fluctuating salinities, compared to R. mangle growing in areas with more constant salinities (Fig. 5). However, the main barrier for water flow in mangroves is probably located in the root, where salt is largely excluded. Experimental studies with Avicennia seedlings showed that both whole shoot hydraulic conductance and leaf blade conductance were reduced by salinity (Sobrado, 2001), a response probably reducing xylem vulnerability to cavitation.

Lovelock et al. (2004) found P deficiency in dwarf Caribbean mangroves and contributed to understanding dwarfism of Rhizophora communities. They fertilized with $\mathrm{P}$ and found a response in increasing branching and a denser canopy. These responses were associated with increases in stem hydraulic conductivity. As described above, dwarf mangroves are characterized by less negative $\delta^{13} \mathrm{C}$ values, indicating their higher water use efficiency, or the more conservative use of water. The increase in stem conductivity is related with reduction in water use-effi-

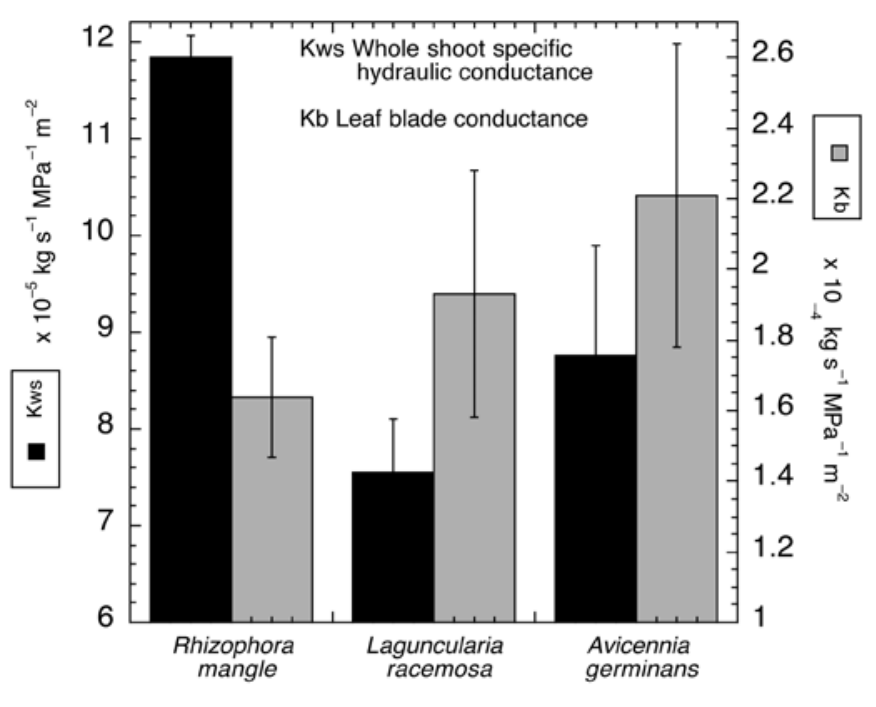

FIGURE 5. Hydraulic characteristics of common mangrove species in the Caribbean region (with data from Sobrado, 2000). Laguncularia racemosa and Avicennia germinans have less efficient water transport at shoot level, but are more efficient in water use at the leaf level in comparison to Rhizophora mangle.

ciency. The process indicates the strong correlation between stomatal function and regulation of water use, leading to a reduction in catastrophic xylem embolism. Further studies by this group (Lovelock et al., 2006a, b) comparing the field performance of mangrove species submitted to fertilization with $\mathrm{P}$ or $\mathrm{N}$, and under different salinity stress in Belize, Panamá, and Florida lead to the conclusion that leaf hydraulic conductivity decreases with salinity, and that leaf and stem conductivity are sensitive to $\mathrm{P}$ fertilization in P-limited sites.

\section{Seasonal Growth Detection BY ANNUAL RINGS}

Estimating the age of tropical trees using dendrochronological techniques has been pursued with variable degree of success. In highly seasonal environment such as the dry tropical forests or forested wetlands with large seasonal flooding in the Amazon basin, formation of annual rings has been clearly demonstrated using anatomical and radiochemical techniques (Worbes, 1999; Schöngart et al., 2002). In 
Rhizophora forests growing on saline and brackish soils in the state of Para in Brazil, Menezes et al. (2003) showed that trees developed annual rings (checked with the ${ }^{14} \mathrm{C}$ technique) but the anatomical features were better defined in saline than in brackish sites. Anatomical analyses showed also the occurrence of annual rings in $L$. racemosa growing in the State of Rio de Janeiro, Brazil (Estrada et al., 2008). The anatomical basis and reliability of annual ring formation have been submitted to severe tests, and the conclusion was that the use of growth rings for age or growth rate determinations should be evaluated on a case by case basis, and accompanied by simultaneous measurements of stem growth (Robert et al., 2011). Even in cases when no welldefined rings are formed, application of high-resolution analysis of stable isotopes $\left({ }^{18} \mathrm{O}\right.$ and $\left.{ }^{13} \mathrm{C}\right)$ has proved annual ciclycity in tree growth (Verheyden et al., 2004).

\section{MANGROVES AND GLOBAL CARBON FluXES}

Today, the global role of mangroves in the carbon cycle is assessed by estimating average values for different fluxes and storages of carbon and multiplying those values by the global area of mangroves (Bouillon et al., 2008). Above we discussed some of the issues that lead to uncertainty in the global area of mangroves. There is also uncertainty with estimates of average fluxes and storages of carbon in mangroves. For example, as shown in the section on the ecophysiology of mangroves, there is no ecophysiological argument to sustain an expectation that given a common set of environmental conditions the mangroves of a particular biogeographical region are more or less productive than those from another biogeographical region. Instead, mangrove functioning varies along ecological space such as along gradients of salinity, temperature, nutrient availability, and so on. The latitudinal differences in carbon fluxes observed by Bouillon et al. (2008) usually reflect latitudinal temperature gradients, with slower fluxes at lower temperatures. But there is more variation in carbon fluxes within a latitudinal range of conditions than across latitudinal gradients. One could argue that the complexity of the mangrove ecosystem rests on the diversity of environmental gradients under which they strive, and unfortunately we have a poor understanding of the magnitude of fluxes and storages of carbon and areal extent for each type of mangrove setting. Such information is needed to accurately assess the global role of mangroves in the carbon cycle.

Alongi (2009) published a synthesis of carbon storages and fluxes in the literature and improved on the earlier efforts reported in Lugo (2002). The average values he reports confirm the notion that mangrove environments are places where the fluxes of carbon are rapid and comparable with other ecosystem types (Table 3). Multiplying

TABLE 3. Carbon fluxes of mangroves and tropical humid forests (from Alongi, 2009).

\begin{tabular}{lcc}
\hline Flux $\left(g C / m^{2}\right.$.yr) & Mangroves & Tropical Humid Forests \\
\hline Gross Primary Production & 4596 & 3551 \\
\hline Net primary Production (NPP) & 1930 & 825 \\
\hline Foliage NPP & 425 & 316 \\
\hline Wood NPP & 419 & 212 \\
\hline Root NPP & 1086 & 324 \\
\hline Net Ecosystem Production & 1018 & 403 \\
\hline Total Ecosystem Respiration & 3125 & 3061 \\
\hline Canopy Respiration & 2644 & 2323 \\
\hline Heterotrophic Respiration & 488 & 877 \\
\hline Total Ecosystem Respiration/ Gross Primary Productivity & $0,68-0,90$ & 0,88 \\
\hline
\end{tabular}


these average numbers by the global area of mangroves (Fig. 1), result in estimates that show that although mangroves may only represent 0,6 percent of the global area of forests and coastal ecosystems, they contribute almost 7 percent of the global respiration and gross primary productivity and 5,2 percent of the global net primary productivity (Alongi, 2009). Moreover, mangroves are particularly important in the burial of carbon (Table 4), and in fact, coastal ecosystems emerge as critical carbon hotspots for the world in what is now known as blue carbon (Mcleod et al., 2011). In general, mangroves function as a global carbon sink (Bouillon et al., 2008).

\section{MANGROVES IN THE CONTEXT OF CLIMATE CHANGE}

In this section we will focus on atmospheric warming and sea level rise to illustrate some of the effects of climate change on mangroves. Mangroves have historically adjusted to sea level and atmospheric temperature changes. While mangroves are generally tropical ecosystems, today one finds mangroves in warm temperate life zones where frost is relative frequent although of low intensity. Mangroves at these low air temperature fringes have low stature, are monospecific (usually an Avicennia species), and exhibit particular leaf color, as they lack the lush green- ness typical of tropical mangroves. With global warming, the life zones where mangroves can grow will expand, allowing mangroves to also expand latitudinally. Already mangroves are invading Spartina and freshwater tidal wetlands in the Mississippi delta (see the report and pictures by Karen L. McKee in http://www.nwrc.usgs.gov/ factshts/2004-3125/2004-3125.htm), and hurricanes are transporting mangrove propagules to the beaches of North Carolina.

Temperature. Air temperature rise may affect mangroves because their present optimum temperatures for photosynthesis are a little above $30^{\circ} \mathrm{C}$. Temperature increases may be manageable as several mangrove species avoid overheating through a high degree of leaf inclination. Increasing nocturnal temperatures however, may be more stressful due to increases in carbohydrate losses during nocturnal respiration, a process that will affect all forests in tropical regions. However, to a certain extent acclimation of physiological processes might be expected.

Rainfall. The effect of changes in rainfall patterns may be more insidious due to the distribution of mangroves in intertidal zones. Those species located near or at the water fringe are less vulnerable because their salinity environ-

TABLE 4. Carbon sequestration in sediments (burial) of coastal vegetation (blue carbon) compared with terrestrial forests of various latitudes. Data are from Mcleod et al. (2011), who contains details of the estimates and statistical analyses.

\begin{tabular}{lcll}
\hline Ecosystem & $\begin{array}{l}\text { Sedimentation } \\
\left(\mathrm{g}\left(\mathrm{m}^{-2} \mathrm{yr}^{\prime}\right)\right.\end{array}$ & \multicolumn{1}{c}{$\begin{array}{c}\text { Area } \\
\left(\mathrm{km}^{2}\right)\end{array}$} & $\begin{array}{c}\text { Global } \\
\text { Sedimentation } \\
\left(\mathrm{Tg} C \mathrm{yr}^{\prime}\right)\end{array}$ \\
\hline $\begin{array}{l}\text { Herbaceous halophytic } \\
\text { wetlands }\end{array}$ & 218 & 22000 to 400000 & 4,8 a 87,2 \\
\hline Mangroves & 226 & 137760 to 152361 & 31,1 a 34,4 \\
\hline Marine sea grasses & 138 & 177000 to 600000 & 48 a 112 \\
\hline Temperate Forests & 5.1 & 10400000 & 53,0 \\
\hline Tropical Forests & 4.0 & 19622846 & 78,5 \\
\hline Boreal Forests & 4.6 & 13700000 & 49,3 \\
\hline
\end{tabular}


ment is stabilized by the influence of tides. In the areas away from the fringe, at the upper reaches of tidal inundation, salt tends to accumulate creating at times hypersaline flats. Salt concentration in those areas is usually reduced through outwashing by superficial runoff and direct rainfall. Species growing near or within those areas will certainly be affected by reductions in rainfall. In fact, this process may be observed during past and current cycles of dry and wet periods, during which populations of A. germinans, the species characteristically associated with salt flats in semi-arid coasts, expand during wet years and contract markedly during dry years (Cintrón et al., 1978).

Sea Level. Regarding sea level changes, McKee et al. (2007) showed that for over the last 10000 years, mangroves in the Caribbean kept pace with sea level rise that involved rates of up to $5,2 \mathrm{~mm} / \mathrm{yr}$ and more recently 0,9 $\mathrm{mm} / \mathrm{yr}$. Unpublished work by E. Cuevas, E. Medina, and A.E. Lugo in Puerto Rico confirmed this result. They found a dwarf mangrove stand growing over peat deposits that aged some 4500 years. The peat was 100 percent organic and consisted of dead mangrove roots. Studies from other parts of the world show that the ability of mangroves to keep up with sea level rise is variable and depends on local conditions and hydrogeomorphic setting of mangroves (Alongi, 2008; Krauss et al., 2010). Thus, some mangroves will be more successful than others in keeping pace with future sea levels, requiring attention to the diversity of conditions under which mangrove grow.

Mangroves adjust to sea level changes by adjusting the level of the substrate through biotic accumulation of peat and/or terrigenous sediments. Where there is no terrestrial runoff, as in the locations studied by McKee et al. (2007), the depth, age, and accumulation rate of peat deposits coincided with the rate of sea level rise. However, if there is a terrestrial source of sediments, the soil elevates in proportion to sedimentation and peat accumulation rate. Table 3 shows that on average the net production of roots in mangroves is as high as that of leaves, supporting the capacity of mangroves to produce belowground car- bon that directly contributes to the raising of mangroves above sea level.

In spite of the adaptations of mangroves to adjust to sea level, there is concern that anthropogenic sea level rise could affect mangrove distribution. Nicholls and Cazenave (2010) analyzed the recent and predicted rates of sea level change and showed that between 1992 and 2010 sea level increased at a $3,26 \mathrm{~mm} / \mathrm{yr}$ rate. Predictions for the future range widely (up to $18 \mathrm{~mm} / \mathrm{yr}$ ). The question from a mangrove perspective is the nature of the response of the whole ecosystem. Mangroves have two ways of coping with sea level rise. They can both raise the forest floor and keep pace with sea level, or they can migrate inland. Each of these strategies has limits. Their capacity for keeping pace with sea level depends on their productivity and rate of sedimentation while their ability to migrate depends on the availability of space to do so.

In south Florida, where the topography is flat, mangroves migrated 3,3 km inland between 1940 and 1994 in response to a $10 \mathrm{~cm}$ sea level rise (Ross et al., 2000). Mangrove migration is favored as sea level rises because the ocean's inland incursion increases soil salinity thus allowing mangroves to successfully move inland over freshwater wetlands.

The potential conversion of freshwater tidal wetlands to saline wetlands in southeastern United States can be surmised from the detailed analysis of these tidal freshwater wetlands in Conner et al. (2007). They show that the geomorphological settings for these wetlands are similar to those of mangroves. The fundamental differences in environmental settings between these two groups of wetlands are two. The most important is salinity, present only in the mangroves. Another difference is temperature, which decreases with latitude and thus limits mangrove expansion northward. Ning et al. (2003) estimated that as many as 640000 ha of coastal maritime forests would be displaced by marshes and mangroves by 2100. Doyle et al. (2010) predict large increases in mangrove areas along the northern Gulf of Mexico, increases that occur at the expense of freshwater wetlands due to sea level rise. Similar model simulations of 
sea level rise in south Florida yield similar results, already validated by the inland migration of mangroves within the Everglades. However, in the south Florida example of Ross et al. (2000), temperature differences were not significant over the 50-year period of the study and the mangroves expanded mostly in response to increasing soil salinity due to rising sea level. As air temperatures increase, the latitudinal expansion options for mangroves also increase. However, where geomorphological settings are unfavorable for mangrove expansion, the migration routes will be limited.

Ellison and Stoddart (1991) estimated that mangroves could keep up with sea level increases of $0,8 \mathrm{~mm} / \mathrm{yr}$ to $0,9 \mathrm{~mm} / \mathrm{yr}$ but would have difficulties with sea level increases over 1,2 mm/yr. They based their assessment on the rates of mangrove floor uplifting by sediment deposition, which Parkinson et al. (1994) estimated as ranging from $1 \mathrm{~mm} / \mathrm{yr}$ to 13,3 mm/yr. Saenger (2002) assembled a global database on mangrove accretion rates determined by a variety of methods, which ranged from $0,1 \mathrm{~mm} / \mathrm{yr}$ to $38 \mathrm{~mm} / \mathrm{yr}$., with rates commonly approaching $5 \mathrm{~mm} / \mathrm{yr}$. A recent summary by Krauss et al. (2010) includes data within the range of Saenger, but it also reports negative values throughout the world. Mangroves on islands or in dry coastal zones with low sediment inputs would be the most vulnerable to sea level rise as the terrigenous inputs of sediments would be lower than those of mangroves in alluvial environments. Since sea level is already rising at $3,26 \mathrm{~mm} / \mathrm{yr}$, and is expected to accelerate in the future, it becomes critical to understand the scenarios of sea level rise and sedimentation rates likely to affect mangroves. Such scenarios require consideration not only of sea level rise, but also of potential costal subsidence or accretion and periodic erosion events due to disturbances such as hurricanes or tidal and wave surges. Also, the present level of mangrove floors above sea level provide a time buffer to mangroves as sea level rise would have to overcome the sum of forest floor elevation plus rate of sedimentation. Mangrove floor elevations usually range between $40 \mathrm{~mm}$ and $90 \mathrm{~mm}$ above seas level. In some cases mangroves have been reported at $3600 \mathrm{~mm}$ above sea level, but these are the result of historical accidents (Woodroffe, 1995 and references therein).

In summary, the eventual outcome of the effects of sea level rise on mangroves will not displace mangroves from coastal environments nor will the mangrove ecosystem collapse globally. Instead, mangroves will prevail where favorable ecological conditions for their establishment and growth occur. Nevertheless, those ecological conditions that select for mangroves (the mangrove ecological space) will be displaced both locally and globally. At the global scale, warming of the atmosphere will allow mangroves to expand into warm temperate life zones not available to them today because of high frost frequencies. At the local scale, mangrove survival to sea level rise will depend on geomorphological conditions, with mangroves expanding at the expense of non-mangrove vegetation in locations that become saline but retain the low energy fringes, basins, or riverine geomorphologies where mangroves grow best. Fringes around islands may be reduced in width or disappear if island topography is not suitable for mangrove establishment at higher sea levels, or where their movement is thwarted by adjacent human land uses or impediments.

\section{MANGROVES AND THE ANTHROPOCENE}

The Anthropocene expands the suite of environmental challenges that mangroves will have to overcome. For example, in the Anthropocene, mangroves must deal with their normal disturbance regime of acute and chronic events plus novel acute and chronic anthropogenic disturbances and novel acute and chronic disturbances that reflect the interaction between natural and anthropogenic forces (Table 5). Thus, the Anthropocene will challenge mangroves with a novel disturbance regime to which the mangroves must somehow adapt or else not be able to survive. Scientists differ in their expectations when looking at the current and future condition of mangroves. It is clear that this is a moment of exuberance regarding human attitudes towards mangroves. Some predict that mangroves might not recover after high intensity hurricanes (Smith et al., 1994), and highlight the negative effects on 
TABLE 5. Examples of disturbance regimes based on natural or historical conditions, anthropogenic conditions, and their synergy. Acute stands for short-duration disturbances and chronic for long-duration ones. Not depicted is the intensity and aerial extent of the disturbances.

\begin{tabular}{lll}
\hline Type of Disturbance & Acute & Chronic \\
\hline Natural & Hurricane, flood & Drought, low nutrient availability \\
\hline Anthropogenic & Deforestation, fire & Eutrophication, alteration of geomorphology, \\
\hline Synergy & Tsunami on developed & Sedimentation from upstream urban sources, lower freshwa- \\
& coast & ter inflows \\
\hline
\end{tabular}

mangrove areas of anthropogenic activities (Valiela et al., 2001). Sectors of society in Hawaii and China do not value mangroves and support programs to pursue their eradication (e.g., Ren et al., 2009; see http://www.malamaopuna.org/waiopae.php). On the other hand, mangroves are expanding in Hawaii, and China as they are in New Zealand, the United States, Cuba, and Puerto Rico. In most countries with mangroves, conservation groups and/or governments are planting mangroves to protect coastal zones and for other services. In Yucatán, Mexico, forensic ecology has been proposed as a way of approaching mangrove restoration efforts (Zaldívar Jiménez et al., 2010). Clearly there is confusion as to what to do with an ecosystem that at one time was an ecological curiosity for its capacity to grow in seawater and was considered a dangerous wasteland (Lugo and Snedaker, 1974).

We agree with Hogarth (2007), who suggested that the solution to mangrove persistence is not to isolate mangroves from people, but to regulate interactions between mangroves and humans through effective management. In fact, we might have to expand the scope of the ecological analysis of mangroves to include the social forces converging on the mangroves in what has been termed Social Ecology. The concept of resilience, which depends not only on a system's reaction to change, but also on its capacity for learning and adaptation is fundamental to the social ecological approach to analyzing and managing people-nature relations (Berkes et al., 2003; Glaser et al., 2010). This need to broaden the scope of analysis is illustrated by the situation facing the managers of the Marismas Nacionales de
Nayarit in the northern Pacific coast of Mexico. This mangrove ecosystem extends over 113000 ha (the estuarine forest wetlands of Marismas Nacionales extend over 175000 ha: Blanco y Correa et al., 2011) and is recipient of water discharges as high as 6 to 9 thousand $\mathrm{m}^{3} / \mathrm{s}$ from upland watersheds that cover over 1 million ha. The biodiversity of the mangrove region is notable and involves plant and animal species of high conservation value as well as rich fisheries associated with the mangroves and the coastal environment. Nevertheless, the lands that feed these mangroves with freshwater runoff, sediments, and nutrients are highly fragmented by the construction of canals and alterations of the topography to such a degree that the normal hydrology of the mangroves is far from what the historical regime was. The alterations have to do with the agricultural development of the region, which now conflicts with the ecological imperative of the mangroves (Benítez-Pardo et al., 2002). The resulting social, ecological, and economic situation is extremely complicated and exhibits the inextricable ties between people and the environment that cannot be resolved by traditional disciplinary approaches. The trans-discipline of Social Ecology represents a novel approach for dealing with the novel conditions faced by the mangroves of Nayarit.

\section{WHAT TO EXPECT FOR MANGROVES IN THE ANTHROPOCENE}

We have already established that the mangroves of the Anthropocene will be on the move as a result of sea level rise and atmospheric warming. Sea level rise will inundate 
and drown some mangrove areas and will stimulate the landward movement of mangroves where conditions allow it. This will involve competition and reassembly of communities of halophytic species and possible displacement of non-halophytic species. Latitudinally, mangroves could extend their distribution to locations where they could not grow before due to high frost frequency. This expansion will involve competition with herbaceous halophytes such as Spartina (Kangas and Lugo, 1990). However, Peterson and Bell (2012) showed that at the mangrove-salt-marsh ecotone, facilitation processes among species increased the movement of Avicennia into the salt-marsh.

The movement of mangrove species by humans will also expand mangroves to locations where they do not occur naturally, as is already the example of Hawaii and French Polynesia (Fourqurean et al., 2010). Humans also introduce the possibility of competition between old-world and new world mangrove species in areas where humans become the vectors of bio-geographical change. An example of this is a mangrove forest in Miami, Florida, where the Fairchild Botanical Garden introduced several oldworld mangrove species, two of which are now expanding at the expense of native mangrove species (Fourqurean $e t$ al., 2010). The naturalization of Bruguiera gymnorrhiza and Lumnitzera racemosa in south Florida is a harbinger of increased diversification of Neotropical mangroves should the introduction of Indo-Pacific mangroves continue. Fourqurean et al. (2010) also give examples where new world mangroves have been introduced into old-world mangroves as in China. All these movements of mangrove species open the development of novelty and novel ecosystems, i.e., new species combinations sensu Hobbs et al., 2013, into mangrove environments.

The level of functioning of Anthropocene mangroves is more difficult to predict than is the expected movements of mangrove species. A confounding problem is that we don't understand the direction of change in such critical variables as those associated with the hydrology of the mangroves. The forces of urbanization can cause havoc with regional hydrological conditions, which in turn will affect mangroves and other coastal systems. Also, chan- ges in mangrove substrates due to filling near urban areas in south Florida, result in mangroves with novel plant-soil interactions (Osland et al., 2012). Moreover, it is difficult to predict how mangrove systems will respond to warming given the indirect effects of salinity, freshwater availability, and atmospheric $\mathrm{CO}_{2}$ increase. The critical action is to promote coordinated ecophysiological and ecosystem level studies of mangroves under the influence of changing conditions associated with the Anthropocene within an adaptive conservation and management strategy, at local to global levels. The most obvious generalization about conservation of mangroves, and any other tropical ecosystem in the Anthropocene, is that such actions must be based on research relevant to the factors of change affecting the ecosystems. The Anthropocene is characterized by the uncertainty associated with human actions. Thus, research must focus its efforts on dealing with uncertainty and conservation and management strategies must incorporate adaptive, flexible, diverse and, where possible, reversible elements. A better understanding of how to achieve this is best done in mangrove systems already dealing with anthropogenic effects.

\section{ACKNOWLEDGEMENTS}

This research was done in collaboration with the University of Puerto Rico. We thank the contribution of Mildred Alayón with the editing and improvement of the manuscript and Samuel Moya for also reviewing the manuscript. Logan Spicer contributed to the gathering of reprints.

\section{LITERATURE CITED}

Almeida Magris, R. and R. Barreto, R. 2010. Mapping and assessment of protection of mangrove habitats in Brazil. Panamerican Journal of Aquatic Sciences 5(4):546-556.

Alongi, D.M. 2008. Mangrove forests: resilience, protection from tsunamis, and responses to global climate change. Estuarine Coastal and Shelf Science 76:1-13.

Alongi, D.M. 2009. The energetics of mangrove forests. Springer, New York, NY. 216 pp.

Bacon, P.R. 1990. Ecology and management of swamp forests in the Guianas and Caribbean region. In: A.E. Lugo, 
M.M. Brinson and S. Brown, eds. Forested wetlands. Ecosystems of the World 15. Elsevier. P: 213-250.

Baldwin, A., M. Egnotovich, M. Ford and W. Platt. 2001. Regeneration in fringe mangrove forests damaged by hurricane Andrew. Plant Ecology 157:149-162.

Ball, M.C. 1988. Ecophysiology of mangroves. Trees 2:129-142.

Ball, M.C., L.R. Cowan and G.D. Farquhar. 1988. Maintenance of leaf temperature and the optimization of carbon gain in relation to water loss in a tropical mangrove forest. Australian Journal Plant Physiology 15:263-76.

Benítez Pardo, D., E. Flores Verdugo and J.I. Valdez Hernández. 2002. Reproducción vegetativa de dos especies arbóreas en un manglar de la costa norte del Pacífico mexicano. Madera y Bosques 8(2):57-71.

Berkes, F., J.F. Colding and C. Folke, editors. 2003. Navigating nature's dynamics: building resilience for complexity and change. Cambridge University Press, New York, $393 \mathrm{pp}$.

Berry, J. and O. Björkman. 1980. Photosynthetic response and adaptation to temperature in higher plants. Annual Review of Plant Physiology 31:491-543.

Biebl, R. 1965. Temperaturresistenz tropischer Pflanzen auf Puerto Rico (Verglichen mit jener von Pflanzen der gemässigten Zone). Protoplasma 59:133-156.

Blanco y Correa, M. (Ed.), F. Flores Verdugo, M. A. Ortiz Pérez, G. de la Lanza Espino, J. López Portillo, I. Valdéz Hernández, C. Agraz Hernández, S. Czitrom, E. Rivera Arriaga, A. Orozco, G. A. Jiménez Ramón, D. Benítez Pardo, J. Gómez Gurrola, A. Á. González Díaz, M. Soria Barreto, G. Otis Kruse, E. A. Jacobo Sapién, G. López Cano, H. Blanco Fuentes y R. Blanco Fuentes. 2011. Diagnóstico Funcional de Marismas Nacionales. Informe final de los convenios de coordinación entre la Universidad Autónoma de Nayarit y la Comisión Nacional Forestal con el patrocinio del Gobierno del Reino Unido, Tepic, Nayarit. 190 pp.

Bouillon, S., A.V. Borges, E. Castañeda-Moya, K. Diele, T. Dittmar, N.C. Duke, E. Kristensen, S.Y. Lee, C. Marchand, J.J. Middelburg, V. Rivera-Monroy, T.J. Smith and R.R. Twilley. 2008. Mangrove production and carbon sinks: a revision of global budget estimates. Global Biogeochemical Cycles 22:GB2013, doi:2010.1029/2007GB003052.
Cheeseman, J.M., L.B. Herendeen, A.T. Cheeseman and B.F. Clough. 1997. Photosynthesis and photoprotection in mangroves under field conditions. Plant, Cell and Environment 20:579-588.

Cheeseman, J.M. and C.E. Lovelock. 2004. Photosynthetic characteristics of dwarf and fringe Rhizophora mangle L. in a Belizean mangrove. Plant, Cell and Environment 27:769-780.

Cintrón, G., A.E. Lugo, D.J. Pool and G. Morris. 1978. Mangroves of arid environments in Puerto Rico and adjacent islands. Biotropica 10:110-121.

Clough, B.F. 1984. Growth and salt balance of the mangroves Avicennia marina (Forsk.) Vierh. and Rhizophora stylosa Griff. in relation to salinity. Australian Journal of Plant Physiology 11:419-430.

Conabio. 2009. Manglares de México: Extensión y distribución. $2^{a}$ ed. Comisión Nacional para el Conocimiento y Uso de la Biodiversidad. México. 99 pp.

Conner, W.H., T.W. Doyle and K.W. Krauss, editors. 2007. Ecology of tidal freshwater forested wetlands of the southeastern United States. Springer, Dordrecht, The Netherlands. 505 pp.

Crooks, S., D. Herr, J. Tamelander, D. Laffoley and J. Vandever. 2011. Mitigating climate change through restoration and management of coastal wetlands and near-shore marine ecosystems: challenges and opportunities. Environment Department, Paper 121, World Bank, Washington, DC.

Crutzen, P.J. 2002. Geology of mankind. Nature 415:23.

Danielsen, F., M.K. Sørensen, M.F. Olwig, V. Selvam, F. Parish, N.D. Burgess, T. Hiraishi, V.M. Karunagaran, M.S. Rasmussen, L.B. Hansen, A. Quarto and N. Suryadiputra. 2005. The asian tsunami: A protective role for coastal vegetation. Science 310 (5748):643.

Demmig, B., K. Winter, A. Krüger and F.C. Czygan. 1987. Photoinhibition and zeaxanthin formation in intact leaves: a possible role of the xanthophyll cycle in the dissipation of excess light energy. Plant Physiology 84:218-224.

Downton, W.J.S. 1982. Growth and Osmotic Relations of the Mangrove Avicennia marina, as Influenced by Salinity. Australian Journal of Plant Physiology 9:519-528. 
Doyle, T.W., K.W. Krauss, W.H. Conner and A.S. From. 2010. Predicting the retreat and migration of tidal forests along the northern Gulf of Mexico under sea-level rise. Forest Ecology and Management 259:770-777.

Duke, N.C., M.C. Ball and J.C. Ellison. 1998. Factors Influencing Biodiversity and Distributional Gradients in Mangroves. Global Ecology and Biogeography Letters $7(1): 27-47$.

Ellison, J.C. and D.R. Stoddart. 1991. Mangrove ecosystem collapse during predicted sea-level rise: Holocene analogues and implications. Journal of Coastal Research 7:151-165.

Estrada G.C.D., C.H. Callado, M.L.G. Soares and C.S. Lisi. 2008. Annual growth rings in the mangrove Laguncularia racemosa (Combretaceae). Trees 22:663-670.

Ewers, F.W., J. Lopez-Portillo, G. Angeles and J.B. Fisher. 2004. Hydraulic conductivity and embolism in the mangrove tree Laguncularia racemosa. Tree Physiology 24:1057-1062.

FAO. 1994. Mangrove forest management guidelines. Food and Agriculture Organization of the United Nations, Rome, Italy. 364 pp.

FAO. 2007. The world's mangroves 1980-2005. FAO Forestry Paper 153, The Food and Agriculture Organization of the United Nations, Rome, Italy. 77 p.

Feller, I.C. 1995. Effects of nutrient enrichment on growth and herbivory of dwarf red mangrove (Rhizophora mangle). Ecological Monographs 65:477-505.

Feller, I.C., C.E. Lovelock, U. Berger, K.L. McKee, S.B. Joye and M.C. Ball. 2010. Biocomplexity in mangrove ecosystems. Annual Review Marine Science 2:395-417.

Feller, I.C., K.L. Mckee, D.F. Whigham, J.O. O’Neill. 2002. Nitrogen vs. phosphorus limitation across an ecotonal gradient in a mangrove forest. Biogeochemistry 62:145-175.

Feller, I.C., D.F. Whigham, J.P. O’Neill and K.L. McKee. 1999. Effects of nutrient enrichment on within-stand cycling in a mangrove forest. Ecology 80:2193-2205.

Fourqurean, J.W., T.J. Smith, III, J. Possley, T.M. Collins, D. Lee and S. Namoff. 2010. Are mangroves in the tropical Atlantic ripe for invasion? Exotic mangrove trees in the forests of south Florida. Biological Invasions 12:2509-2522.

Franks, P. and T.J. Brodribb. 2005. Stomatal control and water transport in the xylem. In: N.M. Holbrook and M.A. Zwienecki, eds. Vascular transport in plants. Elsevier Academic Press Amsterdam p: 69-89.

Fujita, R., J. Lynham, F. Micheli, P.G. Feinberg, L. Bourillón, A. Sáenz-Arroyo and A.C. Markham. 2013. Ecomarkets for conservation and sustainable development in the coastal zone. Biological Reviews, 88:273-286.

Gammage, S., M. Benítez and M. Machado. 2002. An Entitlement Approach to the Challenges of Mangrove Management in El Salvador. AMBIO: A Journal of the Human Environment 31(4):285-294.

Gates, D. M., R. Alderfer and S.E. Taylor. 1968. Leaf temperature of desert plants. Science 151:994-995.

Gibson, C.C., M.A. McKean and E. Ostrom, editors. 2000. People and forests: Communities, institutions, and governance. MIT Press: Cambridge, Massachusetts. 274 pp.

Gilman, E.L., J. Ellison, N.C. Duke and C. Field. 2008. Threats to mangroves from climate change and adaptation options: A review. Aquatic Botany 89:237-250.

Giri, C., E. Ochieng, L.L. Tieszen, Z. Zhu, A. Singh, T. Loveland, J. Masek and N. Duke. 2011. Status and distribution of mangrove forests of the world using earth observation satellite data. Global Ecology and Biogeography 20:154-159.

Glaser, M., G. Krause, R.S. Oliveira and M. Herazo-Fontalvo. 2010. Mangroves and people: A social-ecological system. In: U. Saint Paul and H. Schneider, eds. Mangrove dynamics and management in North Brazil. Ecological Studies Series. Springer Press: Heidelberg, Berlin, p: 307-388.

Golley, F.B., H.T. Odum and R.F. Wilson. 1962. The structure and metabolism of a Puerto Rican red mangrove forest in May. Ecology 43:9-19.

Gravez, V., R. Bensted-Smith, P. Heylings and T. GregoireWright. 2013. Governance Systems for Marine Protected Areas in Ecuador. In: E. Moksness, E. Dahl and J. Støttrup, eds. Global Challenges in Integrated Coastal Zone Management. John Wiley \& Sons, Ltd, Oxford, UK, p:145-158. 
Hobbs, R.J., E.S. Higgs and C.M. Hall, Eds. 2013. Novel ecosystems: intervening in the new ecological world order. Chichester, West Sussex, UK, Wiley-Blackwell. 380 pp.

Hogarth, P.J. 2007. The biology of mangroves and seagrasses. Second edition. Oxford University Press, Oxford, England. $272 \mathrm{pp}$.

Iba, K. 2002. Acclimative response to temperature stress in higher plants: Approaches of gene Engineering for temperature tolerance. Annual Review Plant Biology 53:225-45.

Kangas, P.C. and A.E. Lugo. 1990. The distribution of mangroves and saltmarshes in Florida. Tropical Ecology $31: 32-39$

Kathiresan, K. and B.L. Bingham. 2001. Biology of mangroves and mangrove ecosystems. Advances in Marine Biology 40:81-251.

Komiyama, A., J.E. Ong and S. Poungparn. 2008. Allometry, biomass, and productivity of mangrove forests: A review. Aquatic Botany 89:128-137.

Krauss, K.W., D.R. Cahoon, J.A. Allen, K.C. Ewel, J.C. Lynch and N. Cormier. 2010. Surface elevation change and susceptibility of different mangrove zones to sea-level rise on Pacific high islands of Micronesia. Ecosystems 13.

Krauss, K.W. and M.C Ball. 2013. On the halophytic nature of mangroves. Trees 27:7-11.

Lacerda, L.D., J.E. Conde, P.R. Bacon, C. Alarcón, L. D’Croz, B. Kjerfve, J. Polonia and M. Vannucci. 1993. Mangrove ecosystems of Latin America and the Caribbean: a summary. In: L.D. Lacerda, ed. Conservation and sustainable utilization of mangrove forests in Latin America and Africa regions. International Society for Mangrove Ecosystems and International Tropical Timber Organization Yokohama, Japan p: 1-42.

Liang, S., R.C. Zhou, S. Dong and S. Shi. 2008 Adaptation to salinity in mangroves: Implication on the evolution of salt-tolerance. Chinese Science Bulletin 53:1708-1715.

Lin, G. and L.S.L. Sternberg. 1992a. Comparative study of water uptake and photosynthetic gas exchange between scrub and fringe red mangroves, Rhizophora mangle L. Oecologia 90:399-403.

Lin, G. and L.S.L. Sternberg. 1992b. Differences in morphology, photosynthesis, and carbon isotope ratios between scrub and, fringe mangroves. Aquatic Botany 42:303-313.

López-Portillo, J., F.W. Ewers and G. Angeles. 2005. Xylem conductivity in two mangroves. Plant, Cell and Environment 28:1285-1292.

Lovelock, C.E. and I.C. Feller. 2003. Photosynthetic performance and resource utilization of two mangrove species coexisting in a hypersaline scrub forest. Oecologia $134: 455-462$.

Lovelock, C.E., M.C. Ball, B. Choat, B. Engelbrecht, N.M. Holbrook and I. Feller. 2006a. Linking physiological processes with mangrove forest structure: phosphorus deficiency limits canopy development, hydraulic conductivity and photosynthetic carbon gain in dwarf Rhizophora mangle. Plant, Cell and Environment 29:793-802.

Lovelock, C.E., M.C. Ball, I.C. Feller, B.M.J. Engelbrecht and M.L. Ewe. 2006b. Variation in hydraulic conductivity of mangroves: influence of species, salinity, and nitrogen and phosphorus availability. Physiologia Plantarum $127: 457-464$

Lovelock, C.E., M.C. Ball, K.C. Martin, I. Feller. 2009. Nutrient enrichment increases mortality of mangroves. PLoS ONE 4(5): e5600. doi:10.1371/journal.pone.0005600.

Lovelock, C.E., I.C. Feller, M.C. Ball, B.M.J. Engelbrecht and M.L. Ewe. 2006c. Differences in plant function in phosphorus- and nitrogen limited mangrove ecosystems. New Phytologist 172:514-522.

Lovelock, C.E., I.C. Feller, K.L. McKee, B.M.J. Engelbrecht and M.C. Ball. 2004. The effect of nutrient enrichment on growth, photosynthesis and hydraulic conductance of dwarf mangroves in Panamá. Functional Ecology $18: 25-33$.

Løyche Wilkie, M. and S. Fortuna. 2003. Status and trends in mangrove area extent worldwide. Forestry Department, Forest Resources Assessment Working Paper 63, FAO, Rome, Italy.

Lugo, A.E. 1980. Mangrove ecosystems: Successional or steady state? Biotropica 12 (supplement 2):65-72.

Lugo, A.E. 2002. Conserving Latin American and Caribbean mangroves: issues and challenges. Madera y Bosques $1: 5-25$ 
Lugo A.E. and S.C. Snedaker. 1974. The ecology of mangroves. Annual Review of Ecology and Systematics 5:39-64.

Lugo A.E., E. Medina, E. Cuevas, G. Cintrón, E.N. Laboy Nieves and Y. Schäffer-Novelly. 2007. Ecophysiology of a Fringe Mangrove Forest in Jobos Bay, Puerto Rico. Caribbean Journal of Science 43:200-219.

Lüttge, U. 2002. Mangroves. Environment - Plants - Molecules. In: A. Läuchli , U. Lüttge, eds. Salinity: Kluwer Academics Publishers p: 113-136.

Martinuzzi, S., W.A. Gould, A.E. Lugo and E. Medina. 2009. Conversion and recovery of Puerto Rican mangroves: 200 years of change. Forest Ecology and Management 257:75-84.

McKee, K.L., D.R. Cahoon and I.C. Feller. 2007. Caribbean mangroves adjust to rising sea level through biotic controls on change in soil elevation. Global Ecology and Biogeography 16:545-556.

McKee, K.L., I.C. Feller, M. Popp and W. Wanek. 2002. Mangrove isotopic $\left(\mathrm{d}^{15} \mathrm{~N}\right.$ and $\left.\mathrm{d}^{13} \mathrm{C}\right)$ fractionation across a nitrogen vs. phosphorus limitation gradient. Ecology 83:1065-1075.

Mcleod, E., G.L. Chmura, S. Bouillon, R. Salm, M. Björk, C.M. Duarte, C.E. Lovelock, W.H. Schlesinger and B.R. Silliman. 2011. A blueprint for blue carbon: toward an improved understanding of the role of vegetated coastal habitats in sequestering $\mathrm{CO}_{2}$. Frontiers in Ecology and the Environment 9:552-560.

Medina, E. 1999. Mangrove physiology: the challenge of salt, heat, and light stress under recurrent flooding. In: A. Yáñez-Arancibia and A.L. Lara-Domínguez, eds. Ecosistemas de Manglar en América Tropical, Instituto de Ecología A.C. México. UICN/Orma, Costa Rica, NOAA/NMFS Silver Spring, MD p: 109-126.

Medina, E. 2000. Marine-coastal wetlands: interactions between flooding regime, sedimentation, and salinity. In: Anais do V Simpósio de Ecosistemas Brasileiros: Conservaçao (S. Watanabe, Coordenador) Vol I: Conservaçao e Duna. Publ. Academia de Ciencias do Estado de São Paulo N¹09-1, p: 24-31.

Medina, E. and M. Francisco. 1997. Osmolality and $\delta^{13} \mathrm{C}$ of Leaf Tissues of Mangrove Species from Environments of
Contrasting Rainfall and Salinity Estuarine. Coastal and Shelf Science 45: 337-344.

Medina, E., F. Barboza and M. Francisco. 2005. Occurrence of red mangrove (Rhizophora mangle L.) in the south-western wetlands of the Maracaibo lake: leaf sap analysis detects halophytic physiology in low salinity environments. In: M. Veste, W. Wucherer and J. Homeier, eds. Ökologische Forschung im globalen Kontext. Cuvillier Verlag, Göttingen p:45-54.

Medina, E., E. Cuevas and A.E. Lugo. 2010. Nutrient relations of dwarf Rhizophora mangle L. mangroves on peat in eastern Puerto Rico. Plant Ecology 207:13-24.

Medina, E., E. Cuevas, M. Popp, A.E. Lugo. 1990. Soil salinity, sun exposure, and growth of Acrostichum aureum, the mangrove fern. Botanical Gazette 151:41-49.

Medina, E., A.M. Francisco and A. Quilice. 2008. Isotopic signatures and nutrient relations of plants inhabiting brackish wetlands in the northeastern coastal plain of Venezuela. Wetlands Ecology and Management 16:51-64.

Medina, E., A.E. Lugo and A. Novelo. 1995. Contenido mineral del tejido foliar de especies de manglar de la laguna de Sontecomapan (Veracruz, México) y su relación con la salinidad. Biotropica 27:317-323.

Medina, E., M. Sobrado and R. Herrera. 1978. Significance of leaf orientation for leaf temperature in an Amazonian sclerophyll vegetation. Radiation and Environmental Biophysics 15:131-140.

Mehlig, U., M.P.M. Menezes, A. Reise, D. Schories and E. Medina. 2010. Mangrove Vegetation of the Caeté Estuary. In: U. Saint-Paul and H. Schneider, eds. Mangrove dynamics and management in north Brazil. Ecological Studies, Berlin: Springer pp 71-108.

Mendoza, U.N., C. Cordeiro da Cruz, M.P. Menezes and R.J. Lara. (2012). Flooding effects on phosphorus dynamics in an Amazonian mangrove forest, northern Brazil. Plant and Soil 353:107-121.

Menezes, M., U. Berger and M. Worbes. 2003. Annual growth rings and long-term growth patterns of mangrove trees from the Bragança peninsula, North Brazil. Wetlands Ecology and Management 11:233-242. 
Mora, C. and P.F. Sale. 2011. Ongoing global biodiversity loss and the need to move beyond protected areas: a review of the technical and practical shortcomings of protected areas on land and sea. Marine Ecology Progress Series, 434:251-266.

Naidoo, G. 2006. Factors contributing to dwarfing in the mangrove Avicennia marina. Annals of Botany 97:1095-1101.

Naidoo, G. and D.J. von Willert. 1999. Gas exchange characteristics of the tropical mangrove, Pelliciera rhizophorae. Mangroves and Salt Marshes 3:147-153.

Naidoo, G., A.V. Tuffers and D.J. von Willert. 2002. Changes in gas exchange and chlorophyll fluorescence characteristics of two mangroves and a mangrove associate in response to salinity in the natural environment. Trees 16:140-146.

Nicholls, R. J. and A. Cazenave. 2010. Sea-level rise and its impact on coastal zones. Science 318:1517-1520.

Ning, Z. H., R. E. Turner, T. Doyle and K. Abdollahi. 2003. Preparing for a changing climate. The potential consequences of climate variability and change- Gulf Coast Region. GCRCC, Baton Rouge, LA. 80 pp.

Osland, M.J., A.C. Spivak, J.A. Nestlerode, J.M. Lessmann, A.E. Almario, P.T. Heitmuller, M.J. Russell, K.W. Krauss, F. Alvarez, D.D. Dantin, J.E. Harvey, A.S. From, N. Cormier and C.L. Stagg. 2012. Ecosystem development after mangrove wetland creation: plant-soil change across a 20-year chronosequence. Ecosystems 15:848-866.

Ostrom, E. 2000. Private and common property rights. In: B. Boudewijn and G. De Geest, eds. Encyclopedia of Law and Economics, vol. II. Civil Law and Economics. Edward Elgar, Cheltenham, England. p.332-379.

Pannier, F. 1959. El efecto de distintas concentraciones Salinas sobre el desarrollo de Rhizophora mangle L. Acta Científica Venezolana 10:68-78.

Parida, A.S. and B. Jha. 2010. Salt tolerance mechanisms in mangroves: a review. Trees 24:199-217.

Parkinson, R. W., R.D. DeLaune and J.R. White. 1994. Holocene sea-level rise and the fate of mangrove forests within the wider Caribbean region. Journal of Coastal Research 10(4):1077-1086.

Peterson, J.M. and S.S. Bell. 2012. Tidal events and salt-marsh structure influence black mangrove (Avicennia germi- nans) recruitment across an ecotone. Ecology 93(7):16481658

Pool, D.J., S.C. Snedaker and A.E. Lugo. 1977. Structure of mangrove forests in Florida, Puerto Rico, Mexico, and Costa Rica. Biotropica 9:195-212.

Popp, M. 1984. Chemical composition of Australian mangroves. I. Inorganic ions and organic acids. Z. Pflanzenphysiplogie 113:194-409.

Popp, M. and J. Polania. 1989. Compatible solutes in different organs of mangrove trees. Annales Sciences Forestieres 46 (suppl.):842s-844s.

Popp M., F. Larher and P. Weigel. 1985. Osmotic adaptation in Australian mangroves. Vegetatio 61:247-253.

Popp, M., J. Polania and Weiper M. 1993. Physiological adaptations to different salinity levels in mangrove. In: H. Lieth and A. Al Masoon, eds. Towards the rational use of high salinity tolerant plants. Vol. I, pp. 217-224. Kluwer Academic Publishers.

Reef, R., I.C.Feller and C.E. Lovelock. 2010. Nutrition of mangroves. Tree Physiology 30:1148-1160.

Ren, H., H. Lu, W. Shen, C. Huang, Q. Guo, Z. Li, and S. Jian. 2009. Sonneratia apetala Buch. Ham in the mangrove ecosystems of China: an invasive species or restoration species? Ecological Engineering 35:1243-1248.

Rivera Monroy V.H., R.R. Twilley, E. Medina, E.B. Moser, L. Botero, A.M. Francisco and E. Bullard. 2004. Spatial variability of soil nutrients in disturbed riverine mangrove forests at different stages of regeneration in the San Juan River Estuary, Venezuela. Estuaries 27:44-57.

Robert, E.M.R., N. Koedam, H. Beeckman and N. Schmitz. 2009. A safe hydraulic architecture as wood anatomical explanation for the difference in distribution of the mangroves Avicennia and Rhizophora. Functional Ecology 23:649-657.

Robert, E.M.R., N. Schmitz, J.A. Okello, I. Boeren, H. Beeckman and N. Koedam. 2011. Mangrove growth rings: fact or fiction? Trees 25:49-58.

Ross, M.S., J.F. Meeder, J.P. Sah, P.L. Ruiz and G.J. Telesnicki. 2000. The southeast saline everglades revisited: 50 years of coastal vegetation change. Journal of Vegetation Science 11:101-112. 
Saenger, P. 2002. Mangrove ecology, silviculture and conservation. Kluwer Academic Publishers, Dordrecht, The Netherlands. 360 pp.

Saint Paul, U. 2006. Interrelations among mangroves, the local economy and social sustainability: a review from a case study in north Brazil. In: C.T. Hoanh, T.P. Tuong, J.W. Gowing, and B. Hardy, eds. Environment and Livelihoods in Tropical Coastal Zones, CAB International: Wallingford, UK p.154-162.

Schaeffer-Novelli, Y., G. Cintrón-Molero and R.R. Adaima. 1990. Variability of mangrove ecosystems along the Brazilian coast. Estuaries 13:204-218.

Schmitt, C.B., A. Belokurov, C. Besançon, L. Boisrobert, N.D. Burgess, A. Campbell, L. Coad, L. Fish, D. Gliddon, K. Humphries, V. Kapos, C. Loucks, I. Lysenko, L. Miles, C. Mills, S. Minnemeyer, T. Pistorius, C. Ravilious, M. Steininger and G. Winkel. 2009. Global ecological forest classification and forest protected area gap analysis. Analyses and recommendations in view of the $10 \%$ target for forest protection under the Convention on Biological Diversity (CBD). 2nd revised edition. Freiburg University Press, Freiburg, Germany. http://www.cbd.int/forest/doc/forestgap-analysis_2009_2nd\%20ed.pdf

Scholander, P.F., L. van Dam and S.S. Scholander. 1955. Gas exchange in the roots of mangroves. American J. Botany 42:92-98.

Scholander, P.F., H.T. Hammel, E. Hemmingsen, and W. Garey, 1962. Salt balance in mangroves. Plant Physiology 37:722-729.

Schöngart, J., M.F.T. Piedade, S. Ludwigshausen, V. Horna and M. Worbes. 2002. Phenology and stem-growth periodicity of tree species in Amazonian floodplain forests. Journal of Tropical Ecology 18:581-597.

Smith, J.A.C., M. Popp, U. Lüttge, W.J. Cram, M. Díaz, H. Griffiths, H.J.S. Lee, E. Medina, C. Schäfer, K-H, Stimmel and B. Thonke. 1989. VI. Water relations and gas exchange of mangroves. New Phytologist 111:293-307.

Smith III, T.J., M.B. Robblee, H. Wanless and T.W. Doyle. 1994. Mangroves, hurricanes, and lightning strikes. BioScience 44:256-262.
Sobrado, M.A. 2000. Relation of water transport to leaf gas exchange properties in three mangrove species. Trees $14: 258-262$.

Sobrado, M.A. 2001. Hydraulic properties of a mangrove Avicennia germinans as affected by NaCI. Biologia Plantarum 44:435-438.

Spalding, M., M. Kainuma and L. Collins. 2010. World atlas of mangroves. London, Earthscan 319. 336 pp.

Sperry, J.S., M.T. Tyree and J.R. Donnelly. 1988 Vulnerability of xylem to embolism in a mangrove vs. an inland species of Rhizophoraceae. Physiol Plant 74:276-283.

Suárez, N. and E. Medina. 2006. Influence of salinity on $\mathrm{Na}+$ and $\mathrm{K}+$ accumulation, and gas exchange in Avicennia germinans. Photosynthetica 44 (2):268-274.

Tomlinson, P.B. 1986. The botany of mangroves. Cambridge University Press, New York. 413 pp.

Twilley, R.R. and E. Medina. 1996. Forest dynamics and soil characteristics of mangrove plantations in the San Juan River estuary, Venezuela. In: A. Lugo, ed. Annual Letter, International Institute of Tropical Forestry. U.S. Department of Agriculture, Forest Service, Rio Piedras, Puerto Rico, p:87-94.

Twilley, R.R. and V.H. Rivera Monroy. 2009. Ecogeomorphic models of nutrient biogeochemistry for mangrove wetlands. In: G.M.E. Perillo, E. Wolanski, D.R. Cahoon, and M.M. Brinson, eds. Coastal wetlands: an integrated approach. Elsevier, Amsterdam, The Netherlands.

Valiela, I., J.L. Bowen and J.K. York. 2001. Mangrove forests: one of the world's threatened major tropical environments. BioScience 51:807-815.

Van Lavieren, H., M. Spalding, D.M. Alongi, M. Kainuma, M. Clüsener-Godt and Z. Adeel. 2012. Securing the future of mangroves. United Nations University Institute for Water, Environment and Health, Hamilton, Canada.

Verheyden, A., G. Helle, G.H. Schleser, F. Dehairs, H. Beeckman and N. Koedam. 2004. Annual cyclicity in highresolution stable carbon and oxygen isotope ratios in the wood of the mangrove tree Rhizophora mucronata. Plant, Cell and Environment 27:1525-1536

Walter, H. and M. Steiner. 1936. Die Ökologie der Ost-Afrikanischen Mangroven. Zeitschrift für Botanik 30:65-193. 
Wang, W., Z. Yan, S. You, Y. Zhang Y, L. Chen L and G. Lin. 2011. Mangroves: obligate or facultative halophytes? A review. Trees 25:953-963.

Woodroffe, C. D. 1995. Response of tide-dominated mangrove shorelines in northern Australia to anticipated sea-level rise. Earth Surface Processes and Landforms 20:65-85.

Worbes, M. 1999. Annual growth rings, rainfall-dependent growth and long-term growth patterns of tropical trees from the Caparo Forest Reserve in Venezuela. Journal Ecology 87:391-403

Wyn Jones, R.G. and J. Gorham. 2002. Intra and inter cellular compartmentation of ions a study in specificity and plasticity. In: A Laüchli and U. Lüttge, eds. Salinity: Environ-
ment-Plants-Molecules. Kluwer Academic Publishers, Dordrecht, The Netherlands, p:159-180.

Zaldívar Jiménez, M.A., J.A. Herrera Silveira, C. Teutli Hernández, F.A. Comín, J.L. Andrade, C. Coronado Molina and R. Pérez Ceballos. 2010. Conceptual framework for mangrove restoration in the Yucatán Peninsula. Ecological Restoration 28:333-342.

Manuscrito recibido el 6 de noviembre de 2013

Aceptado el 17 de noviembre de 2014.

Este documento se debe citar como:

Lugo, A. E., E. Medina and K. McGinley. 2014. Issues and Challenges of Mangrove Conservation in the Anthropocene. Madera y Bosques 20(3):11-38. 